DOI

http://dx.doi.org/10.1590/2236-463320151110

Political struggles, abolitionism and the overthrow of slavery: Bananal, 1878-1888.

\title{
Lutas políticas, abolicionismo e a desagregação da ordem escravista: Bananal, 1878-1888
}

Marco Aurélio Santos

Universidade de São Paulo (USP)

\section{RESUMO}

0 objetivo deste artigo é entender as disputas políticas ocorridas no município cafeeiro de Bananal no período entre 1878-1888. Pretendese entender esses conflitos articulando-os a um quadro mais amplo de consolidação, transformação e crise do Estado imperial. Desse modo, analiso a realidade política do Império do Brasil e as disputas políticas advindas de uma situação de instabilidade criada especialmente pelo movimento abolicionista, levando à queda da Monarquia.

\section{ABSTRACT}

The aim of this article is to understand the political struggles in Bananal, an important coffee county in Paraiba Valley in Brazil, between the years 1878-1888. In addition, I try to understand the connections between the town's elite and wider processes of consolidation, transformation and the crisis of the Imperial State of Brazil. In other words, I analyze the political reality of the Brazilian Empire and political struggles that derive from an unstable situation caused mainly by the abolitionists that lead to the fall of the Brazilian Monarchy.

Palavras-chave

abolicionismo, crise política, disputas partidárias.

Keywords

abolitionism, political crisis, political struggles. 
1

AZEVEDO, Elciene. 0 direito dos escravos: lutas jurídicas e abolicionismo na província de São Paulo. Campinas, SP: Ed. da Unicamp, 2010. CARVALHO, José Murilo de. A construção da ordem: a elite política imperial/ Teatro de sombras: a politica imperial. Rio de Janeiro: Civilização Brasileira, 2008. CONRAD, Robert. Os últimos anos da escravatura no Brasil: 1850-1888. Rio de Janeiro: Civilização Brasileira, 1978. FLORY, Thomas. El juez de paz y el jurado en el Brasil imperial. México: Fondo de Cultura Económica 1986. DOLHNIKOFF, Miriam. O pacto Imperial: origens do federalismo no Brasil. São Paulo: Globo, 2005. GOUVÊA, Maria de Fátima Silva. 0 Império das Províncias. Rio de Janeiro, 18221889. Rio de Janeiro: Civilização Brasileira, 2008. MACHADO, Maria Helena. O plano e o pânico: os movimentos sociais na década da Abolição. Rio de Janeiro: Ed. UFRJ, 1994. MENDONÇA, Joseli Maria Nunes. Entre a mão e os anéis: a lei dos sexagenários e os caminhos da abolição no Brasil. Campinas, SP: Ed. da Unicamp, 2008. MATTOS, Ilmar Rohloff de. 0 tempo saquarema. São Paulo: Hucitec, 2004. QUEIROZ, Jonas Marçal de. Da senzala à República: tensões sociais e disputas partidárias em São Paulo (1869-1889). 1995. Dissertação (Mestrado em História) - Instituto de Filosofia e Ciências Humanas, Universidade Estadual de Campinas, Campinas, 1995. TOPLIN, Robert Brent. The abolition of slavery in Brazil. New York: Atheneum, 1975.
Nos últimos anos diversos pesquisadores do Império do Brasil estudaram a estruturação do Estado nacional no século XIX e trabalharam com o abolicionismo e a crise da escravidão. Os estudiosos desses temas foram de fundamental importância para se entender a formação, consolidação e derrocada do Estado Imperial e a agência escrava. A escravidão sempre esteve presente nesses estudos, ora de maneira determinante, ora de modo incidental, como pano de fundo para as análises do funcionamento político do Estado brasileiro. No primeiro grupo, cumpre destacar, sem pretender esgotar a lista de estudiosos sobre esse tema, os trabalhos de José Murilo de Carvalho, Thomas Flory, IImar Rohloff de Mattos, Miriam Dolhnikoff e Maria de Fátima Silva Gouvêa. No que tange aos estudos que focam o movimento abolicionista, destacam-se Elciene Azevedo, Maria Helena Machado, Robert Conrad, Robert Brent Toplin, Joseli Maria Nunes Mendonça e Jonas Marçal de Queiroz'. A crise do Estado imperial e a crise da escravidão são dois processos concomitantes e muitos desses autores estudaram as implicações políticas do abolicionismo e dos movimentos sociais nas décadas finais do Império do Brasil. Os trabalhos do primeiro grupo são de fundamental importância para se entender o funcionamento do poder no século XIX e as articulações desenvolvidas pelos sujeitos entre os diferentes níveis de governo (imperial, provincial e municipal). Já os estudos sobre 0 abolicionismo também se preocuparam com a agência escrava e abordaram a crise política e a crise da escravidão a partir de diversas perspectivas. Distingue-se, nesse último grupo, o mestrado de Jonas Marçal de Queiroz, que estudou a questão das disputas políticas na crise do Estado Imperial, nas décadas de 1870 e 1880. Essa distinção é necessária porque nenhum dos trabalhos citados do segundo grupo (e muitos do primeiro) analisou a crise do Estado imperial da perspectiva das lutas políticas e do esfacelamento do que se convencionou denominar de "classe senhorial".

Esse momento histórico das décadas de 1870 e 1880 pode ser visto como um período de crise do que se convencionou chamar de "direção saquarema", para lembrar a caracterização cunhada por Ilmar Rohloff de Mattos. Isso porque, no foco dos debates analisados neste artigo, e que não se vinculam somente a Bananal, mas que se estendem por diversas partes do Brasil, a escravidão e a abolição foram dois temas centrais do debate político e da atuação dos sujeitos envolvidos.

A historiografia aponta que, após a abdicação do primeiro imperador, d. Pedro I, ocorrida em 7 de abril de 1831, diversas correntes políticas lutaram para reorganizar os fundamentos institucionais do Estado Imperial. Iniciava-se então o periodo regencial, que duraria até a aprovação da maioridade, em 1840. Nesse momento histórico, os saquaremas despontaram como líderes de um processo cujos objetivos eram a segurança, a ordem e a manutenção da escravidão. Para que seu projeto político fosse implementado, os saquaremas assumiram o poder em meados da década de 1830 e guiaram a aprovação de uma série de medidas estruturantes, como as reformas centralizadoras do Judiciário. Um dos principais objetivos dessas reformas seria a garantia da ordem pública, com a criação de mecanismos que pudessem viabilizar o domínio da classe dos proprietários mais ricos. Nesse sentido, a aprovação da lei $n^{\circ} 261$ de 3 de dezembro de 1841 e do Regulamento $n^{\circ} 120$ de 31 de janeiro de 1842 cumpriram um papel de importância crucial para que o projeto político dos saquaremas pudesse funcionar. Esses dois diplomas - o primeiro é a Reforma do Código do Processo Criminal, o segundo o regulamento da execução da parte policial 
2

Thomas Flory. Op. Cit., pp. 279-280. Esse autor continua a analisar os efeitos da lei de 3 de dezembro no capítulo seguinte, denominado "La politica de la justicia, 1841-1871". Nesse capitulo, destaca a importância das nomeações e a interferência do governo central nos interesses locais e na magistratura. 0 papel dos juízes para garantir as conveniências do governo central e a utilização política das remoções desses profissionais para localidades distantes foram práticas que estão intimamente associadas ao funcionamento do sistema político do Império. Ibid. pp. 281-307.

3

No livro de llmar Rohloff de Mattos, isso fica bem evidente, por exemplo, no capitulo intitulado "Os olhos do soberano", onde se lê a respeito de uma ideologia da centralização bem como dos agentes que exerciam, nas Provincias e nas localidades, essa mesma centralização. MATTOS, Ilmar Rohloff de. Op. Cit., p. 211-230. FLORY, Thomas. Op. Cit., p. 282.

4

0 pensamento de Mattos foi seguido de perto por Ricardo Salles, para quem "a precaução contra uma possivel insurreição escrava de largas proporções e de alcance antiescravista - uma possibilidade sempre cogitada depois do Haiti - foi um importante fator de soldagem de solidariedades escravistas para além do âmbito das vivências imediatas deste ou daquele senhor, nesta ou naquela região em particular". Ao lado de outros fatores, essa "precaução conformou, enfim, uma experiência de classe coletiva, histórica, a partir da qual os proprietários individuais de escravos passaram a viver suas vidas, a situar-se no mundo - das fazendas, das vilas, das cidades, mas também do Império, da Europa e da Civilização (...)". Essa afirmação, que considera o período de construção e de amadurecimento do Estado Imperial, grosso modo da década de 1830 até o início do movimento abolicionista em escala nacional, nos anos finais da década de 1870 permite entender um componente fundamental da organização do Estado nacional brasileiro, qual seja, a importância da escravidão como fator estruturante para a atuação da classe senhorial de proprietários de escravos e a robustez do consenso seguido por essa classe em torno das premissas acima apontadas. SALLES, Ricardo. E o Vale era o escravo: Vassouras, século XIX. Senhores e escravos no coração do Império. Rio de Janeiro: Civilização Brasileira: 2008. pp. 45-46. Ver também SALLES, Ricardo. Abolição no Brasil: resistência escrava, intelectuais e política (1870-1888). Revista de Índias, Madrid, vol. LXXI, 2011, 251: 259-284. PARRON, Tâmis. A política da escravidão no Império do Brasil, 1826-1865. Rio de Janeiro: Civilização Brasileira, 2011. pp. 175176. Sobre o conceito de classe senhorial, SALLES, Ricardo. 0 Império do Brasil no contexto do século XIX. Escravidão nacional, classe senhorial e intelectuais na formação do Estado. Almanack: revista eletrônica semestral. Guarulhos/SP: UNIFESP, n. 4, nov. de 2012. pp. 5-45. e criminal dessa mesma lei - são exemplos fundamentais para se entender as articulações que ocorreram entre os três niveis de governo. Dai se estruturou a centralização das atividades policiais e judiciárias do Estado Imperial e, por conseguinte, as articulações entre o "local" e o "central". Para Thomas Flory, os efeitos da lei não se restringiram à centralização das atividades policiais e judiciárias. A lei de 3 de dezembro provocaria também efeitos eleitorais, uma vez que os agentes indicados pelo governo central teriam clara influência nas eleições, na elaboração das listas de votantes etc. Flory entendeu que após as reformas do início da década de 1840, passou a vigorar um "novo sistema eleitoral" que estruturou um "sistema político viável". Por isso, Flory classifica essa legislação como a "carta constitucional não oficial" do Partido Conservador e "a verdadeira constituição política do Império". A partir de então, segundo Ilmar Rohloff de Mattos, ao Estado Imperial seria reservada a função de dominação, de coação e de direção com o propósito fundamental de preservar a escravidão ${ }^{3}$. Vivia-se, então, um movimento de reação a uma conjuntura de instabilidade política e social da Regência, marcada por diversas revoltas sociais, muitas delas com participação efetiva de escravos, e intensos questionamentos quanto aos rumos do Estado e da nação ${ }^{4}$.

Mas há um dado que é importante sublinhar. Os embates existentes nesse momento histórico produziram um arranjo institucional que determinou as características do funcionamento do Estado Imperial até 1889. Esse arranjo caracterizou-se não somente pelo projeto dos saquaremas, mas pela combinação de dois grandes projetos institucionais: aquele que saiu das reformas de caráter liberal do início da década de 1830, especialmente a reforma constitucional de 1834 (conhecida como Ato Adicional) e o projeto dos saquaremas da virada da década de 1830 para a de 1840 . 0 ponto central da reforma de 1834 que interessa a este artigo foi, conforme demonstraram Thomas Flory, Miriam Dolhnikoff e Maria de Fátima Silva Gouvêa, a subordinação dos municípios ao governo provincial e, mais especialmente, à Assembleia Provincial. Segundo Dolhnikoff, o direito de determinar as despesas municipais, de estabelecer os impostos que deveriam ser cobrados, de fiscalizar a aplicação das rendas públicas, de controlar as contas municipais e de criar ou extinguir empregos municipais, além de outras atribuições relativas às municipalidades, ficavam a cargo da Assembleia Provincial. A combinação das reformas do início da década de 1830 e aquelas capitaneadas pelos saquaremas obrigaram os proprietários das localidades a estabelecer vínculos com os níveis provincial e da Corte. 0 estudo de Maria de Fátima Silva Gouvêa sobre a Província do Rio de Janeiro demonstrou o modo como essas articulações ocorriam, quando deputados na Assembleia se mobilizavam para beneficiar os interesses de suas localidades.

Desse modo, este artigo vincula-se às questões suscitadas pela historiografia a respeito do arranjo institucional do Estado Imperial para entender as disputas políticas em Bananal, importante município cafeeiro do Vale do Paraíba paulista. Partindo dos processos criminais dessa localidade e dos periódicos do período 1878-1888, pretende-se entender como essas disputas que ocorreram nesse município, potencializadas pelo movimento abolicionista, sugerem uma interpretação sobre o funcionamento da prática política no Império do Brasil até aqui pouco explorada pelos pesquisadores. Procura-se, assim, relacionar os conflitos partidários que ocorreram nessa localidade com o movimento abolicionista e a crise política em 
5

A noção de "jogo de escalas" remete ao livro organizado por Jacques Revel e de modo mais direto ao seu artigo. Nele, o autor trabalha, entre outras orientações metodológicas, a ideia de redefinição da noção de contexto. Ver REVEL, Jacques. Microanálise e construção do social. In: (org). Jogos de escala: a experiência da microanálise. Rio de Janeiro: Editora FGV, 1996. p. 15-38.

0 conceito de "partido", na cultura política brasileira do século XIX, estava associado mais à ideia de facção ou clientela e, portanto, à definição de redes de lealdade pessoal, do que a um programa estabelecido. As lealdades pessoais e os interesses por cargos eram superiores aos programas partidários. Na acepção de uma comissão do Senado do Império do Brasil, "desgraçadamente, partido quer dizer parcialidade". Ver GRAHAM, Richard. Clientelismo e política do Brasil no século XIX. Rio de Janeiro: Editora UFRJ, 1997. p. 211. Em seu estudo sobre a Província do Rio de Janeiro e os debates na Assembleia Provincial, Maria de Fátima Silva Gouvêa demonstrou que a vinculação com a localidade poderia ser, em alguns casos, um elemento mais forte do que a fidelidade partidária. GOUVÊA, Maria de Fátima Silva. 0p. Cit. p. 187. Ver também o exemplo da nota 106

7

RAMOS, Agostinho. Pequena História do Bananal. São Paulo: Gráfica Sangirard, 1975. p. 272.

8

Sobre a importância de se controlar a mesa eleitoral para obter êxito na eleição ver GRAHAM, Richard. Op. Cit. p. 178. Um dito muito comum no século XIX dizia: "Não podemos dar a campanha eleitoral; a qualificação não é nossa". As fraudes eleitorais iniciavam-se na qualificação dos votantes. A reunião da junta qualificadora era uma exigência legal que acontecia no terceiro domingo do mês de janeiro de cada ano. Soares de Souza denunciou as fraudes que ocorriam nessas reuniões, atestando a participação dos presidentes de Província e do Ministro do Império na corroboração das listas de qualificação falsificadas. 0 mesmo autor também tratou dos abusos cometidos por aqueles que controlavam a mesa eleitoral. SOARES DE SOUZA, Francisco Belisário. 0 sistema eleitoral no Império. Brasilia: Senado Federal, 1979. p. 25-32. A citação acima encontra-se à página 27. 0 trecho "obstar materialmente a organização da mesa paroquial" pode ser interpretado como uma ação resultante da reforma eleitoral de 1875 que definiu, entre outras medidas, a "qualificação definitiva dos votantes". Essa medida parece ter dificultado a interferência dos chefes políticos locais na definição dos votantes, tornando mais rigoroso o processo de qualificação. Anteriormente a essa lei, o procedimento era a alteração da lista de votantes do ano anterior, que poderiam ser incluidos ou excluídos. Com a nova lei, só restava mesmo trabalhar no sentido de impedir materialmente os trabalhos da mesa paroquial. GRAHAM. Richard. Op. Cit. p. 250. escala nacional, entendendo que o Estado Imperial conseguiu estender suas influências às municipalidades (conforme a tese de Ilmar Mattos) e, ao mesmo tempo, subjugou essas mesmas municipalidades às esferas do poder provincial e da Corte (conforme os trabalhos de Miriam Dolhnikoff e Maria de Fátima Gouvêa). A análise terá por base dois momentos importantes da política nacional que interferiram diretamente na atuação dos partidos políticos em Bananal. 0 primeiro deles refere-se ao período liberal, que se iniciou com a ascensão do Visconde de Sinimbu em 5 de janeiro de 1878. Esse período terminou em 20 de agosto de 1885, com a escolha do Barão de Cotegipe, conservador - que, por sua vez, governou até 1888 . Nesses dois momentos, as movimentações políticas dos dois partidos na localidade de Bananal revelam o espaço de atuação dos grandes fazendeiros com ampla projeção política. Como se verá, muitos desses sujeitos tiveram de construir um espaço amplo de atuação e procuraram se articular com os níveis Provincial e da Corte através de uma série de recursos que eram dificeis de alcançar por escravos e homens livres dependentes. Isso revela um interessante "jogo de escalas"5 que uniu os níveis imperial, provincial e local e permitiu que os proprietários rurais da localidade se interligassem com diversas esferas do governo.

Lutas políticas e abolicionismo em Bananal: o período liberal (1878-1885) Os acontecimentos pré-eleitorais ocorridos em julho de 1878 em Bananal são um bom ponto de partida para se entender a política partidária do Império do Brasil. Eles permitem direcionar o debate historiográfico sobre a crise política do Segundo Reinado para o abolicionismo e os conflitos político-partidários, investindo em novos rumos e novas problemáticas até então pouco trabalhados pela historiografia.

Desdobramento do novo período liberal que se inaugurou no Brasil com o Gabinete de 5 de janeiro, os eventos de julho permitem entender a realidade política de Bananal na década final da escravidão. No início desse mês, o comendador Antônio José Nogueira, importante proprietário de escravos, dono da Fazenda da Gloria e conhecido também como Nogueirinha, entrara pelas ruas do centro da cidade de Bananal com cerca de quinze a vinte "cavaleiros ostensivamente armados". Chefe do Partido ${ }^{6}$ Liberal e herdeiro político de seu pai, Nogueirinha era responsável por manter "aceso o facho da política"7. A cena desse "faroeste caboclo" mostrava que a tensão era evidente nesses dias de julho, não só por causa da afronta do agressivo chefe liberal, mas também por uma série de outros episódios que ocorreram nesse mesmo mês. Dentre esses acontecimentos, destacam-se o do dia 5 de julho - em que um cidadão "foi atirado (sic), não tendo sido felizmente atingido" somente porque não cumprimentou o comendador Nogueira - e o do dia 14 - quando os inspetores de quarteirão reuniram-se no centro da cidade e receberam ordem para congregar o povo no dia $1^{\circ}$ de agosto, reforçando os boatos de que o chefe liberal pretendia "obstar materialmente a organização da mesa paroquial"8. Os partidários conservadores de Bananal acusavam o "ardor político" de Nogueirinha, que tencionava a vitória eleitoral, procurando dificultar os preparativos para a eleição primária, marcada para o dia 5 de agosto. Segundo a reclamação dos conservadores, o comendador contava com a "conveniência das autoridades judiciárias" e mobilizava a polícia que se dirigia diariamente à Praça Municipal e fazia "exercícios marciais, perturbando o sossego público com descargas de fuzil". Quem contestava os "abusos" era preso, ficando 
9

Arquivo Público do Estado de São Paulo (doravante AESP). Ofícios diversos de Bananal: 1869-1891. Caixa 35. Ordem 829. Pasta 3. Doc. 41 e 41-A. Ofício datado de 20 de julho de 1878 e endereçado ao Presidente da Província, João Baptista Pereira.

10

Correio Paulistano. 17/02/1878. Edição 6384. p. 2. Essa edição apresenta as nomeações para Delegado de Polícia e três suplentes e a nomeação de três suplentes para o cargo de subdelegado. Todos os nomeados eram liberais, sendo que eles serão eleitos em 5 de agosto como eleitores (Geral e Especial). Ver a relação dos eleitos no Correio Paulistano. 13/08/1878. Edição 6525. p. 3-4. Essa edição fala do convênio entre as duas parcialidades.

11

Correio Paulistano. 09/03/1879. Edição 6689. p. 2. Ver também Correio Paulistano. 21/03/1879. Edição 6699. p. 1-2. "um dia e mais" na Cadeia. As notícias também se referiam a atentados que estavam sendo planejados para o dia da eleição por agentes policiais com vistas a eliminar os "membros mais proeminentes da oposição" que se apresentassem para votar. Para finalizar, denunciava-se que o comendador Nogueirinha possuía mais de cem "espingardas modernas" para impedir os votantes conservadores de entrarem na Igreja para votar no dia da eleição ${ }^{9}$.

No plano local, os conflitos políticos entre liberais e conservadores estavam acirrados, dado o conjunto de nomeações e exonerações que se produziu com o novo governo. Delegados de Polícia e outras autoridades públicas, além dos chefes locais, começaram a se envolver em entreveros públicos, exibindo à população de escravos e homens livres o modus operandi dos novos donos do poder. A violência narrada, que antecedeu às eleições de 5 de agosto, redundou em um "convênio", como relatou o Correio Paulistano de 13 de agosto. Desse acordo pacificador saiu um arranjo eleitoral que definiu a escolha dos eleitores gerais e dos eleitores especiais. Os liberais conseguiram a maioria nas duas categorias de eleitores ${ }^{10}$.

As lealdades pessoais e as fortes cisões partidárias marcaram a prática política em diversas partes do Brasil. Em Bananal, as rivalidades entre liberais e conservadores estavam assentadas nas divisões que surgiram após a "Revolução Liberal de 1842". Nessa época, os meio-irmãos Luciano José de Almeida e Antônio José Nogueira (pai) passaram a se enfrentar, 0 primeiro como conservador e o segundo como liberal. A partir de então, as desavenças familiares redundaram em confrontos políticos. Como resultado do projeto nacional implementado pelos saquaremas, no plano local muitos poderosos agiam no sentido de cooptar agentes públicos, agregados e homens livres em geral com o desígnio de conseguir benefícios pessoais e influência política. Esse aliciamento clientelístico construiu um espaço de atuação que se estendeu das terras senhoriais à máquina pública municipal, por intermédio dos escrivães, juízes, entre outros, passando pelo governo provincial e chegando à Corte.

Um dos desentendimentos entre liberais e conservadores desse período foi o que ocorreu em 11 de agosto de 1879. Nesse dia, o conservador José Luiz de Almeida Nogueira, político eminente e deputado à Assembleia Provincial, foi "agredido e gravemente ferido, em plena luz do dia e junto à coletoria". Dentre os envolvidos nas agressões ao político estavam delegados e seus suplentes, todos partidários liberais.

Almeida Nogueira costumava denunciar na Assembleia Provincial os desmandos dos liberais. Em sessão de 8 de março, reclamou do "despotismo policial" que imperava na cidade do Bananal e denunciou a falta de energia e imparcialidade das autoridades judiciárias. 0 deputado protestou, por exemplo, contra a ação dos segundo e terceiro suplentes do delegado. Textualmente: "o $2^{\circ}$ suplente em exercício [Elpídio Rodrigues Seixas] é homem ignorante e apaixonado, tem cometido muitos abusos e ainda ultimamente efetuou ilegalmente a prisão de um cidadão pacífico, fazendeiro, capitalista e eleitor, o qual, no exercício de seu direito, mandava levar ao curral do conselho animais pertencentes ao delegado e que haviam sido encontrados em terras do referido cidadão, que é o sr. José Ferreira Leão". Segundo a denúncia de Almeida Nogueira, um conflito entre fazendeiros vizinhos teria gerado um ato arbitrário por parte do segundo suplente do delegado. Por trás dessa refrega estavam rivalidades partidárias. 0 deputado finalizava dizendo que em Bananal não existia lei para as autoridades policiais ${ }^{11}$. 
Correio Paulistano. 13/08/1879. Edição 6816. p. 2 e Correio Paulistano. 17/08/1879. Edição 6819. p. 1.

13

Gazeta de Notícias. 17/08/1879. Edição 225. p. 3. Ver também Correio Paulistano. 24/08/1879. Edição 6825. p. 1; Correio Paulistano. 26/08/1879. Edição 6826. pp. 1-2; 0 Mequetrefe. 20/08/1879. Ano 5. Número 180. p. 2. 0 irmão de Almeida Nogueira, Pedro Ramos Nogueira, manifestou-se no Correio Paulistano. 27/08/1879. Edição 6827. p. 1. Ver também o artigo assinado por "C." na página 2 dessa mesma edição. $A$ atuação do chefe de polícia é criticada no Correio Paulistano. 28/08/1879. Edição 6828. p. 1 e no Correio Paulistano. 29/08/1879. Edição 6829. p 1. Especialmente nesse último número, vê-se, na denúncia feita pelo Correio Paulistano, que os vínculos entre o Presidente da Província, o chefe de polícia e os chefes locais são usados para garantir a impunidade. Claro que essas críticas podem ser vistas com desconfiança, uma vez que o Correio Paulistano tinha orientação conservadora. De qualquer modo, elas revelam o funcionamento da política no século XIX, com as novas redes de clientelismo sendo construídas a cada mudança de Gabinete.

14

Segundo Ilmar R. de Mattos, o chefe de polícia teve suas atribuições definidas "de modo preciso" na lei $n^{\circ} 261$ de 3 de dezembro de 1841. MATTOS Ilmar Rohloff de. Op. Cit. p. 223-224.

15

Correio Paulistano. 23/01/1880. Edição 6949. p. 2.
0 caso de violência física ao deputado teve ampla repercussão, gerando debates no Senado, e aos poucos a tentativa de agressão transformou-se, no Correio Paulistano, em tentativa de assassinato. Segundo José de Magalhães Couto, correligionário de Almeida Nogueira, no dia da agressão os liberais realizaram uma reunião para "deliberar sobre uma manifestação de aplauso ao seu chefe o comendador Nogueira"12. No jogo de versões e contraversões, típico da imprensa partidarizada do Império do Brasil, José Ramos da Silva rebateu, na Gazeta de Notícias, o ponto de vista dos conservadores. 0 entrevero teria sido tão somente uma luta "braço a braço" entre os dois. Silva reclamou nesse artigo da campanha capitaneada pelo Monitor Paulista, periódico publicado em Bananal e pertencente a Almeida Nogueira. Como resultado dessas investidas do jornal dos conservadores, os liberais fizeram uma reunião "com o fim de assinarem uma manifestação de confiança e adesão" ao comendador Nogueirinha. Depois de terminada a reunião, os liberais teriam se encontrado com Almeida Nogueira em frente à coletoria e daí teria resultado a luta entre os dois ${ }^{13}$.

As querelas partidárias entre as duas parcialidades revelavam os elos que vinculavam a localidade à Presidência da Província e ao Gabinete ora no poder. A arena de lutas e manifestações acontecia não somente na localidade, mas também nos âmbitos provincial e da Corte. 0 foco das notícias veiculadas pelo Correio Paulistano questionou a atuação do chefe de polícia no caso envolvendo a agressão a Almeida Nogueira, sua responsabilidade para instaurar o processo e as comunicações estabelecidas entre essa autoridade e o Presidente de Província ${ }^{14}$. Nesse sentido, a edição de 23 de janeiro desse jornal transcreveu notícia do Monitor Paulista sobre esse atentado. Informou-se que o político conservador processava três pessoas que o haviam agredido. Esses réus seriam protegidos por poderosos locais e estariam seguros da impunidade de seus atos. Os "poderosos protetores" estavam agindo para a escolha dos jurados, incluindo na lista de qualificação de jurados "pessoas moral e legalmente ineptas". Em desacordo com os artigos 28 e 29 da lei de 3 de dezembro de 1841 e dos artigos 226, 227, 229 e 233 do regulamento $n^{\circ} 120$ de 31 de janeiro de 1842, a notícia informava como era importante que o juiz de direito, o promotor público, o presidente da câmara municipal e o delegado fossem aliados dos donos do poder. Assim, seria possivel garantir um corpo de jurados condescendente e que agisse para promover a impunidade ${ }^{15}$.

No dia 17 de fevereiro de 1880, o Correio Paulistano publicou o longo recurso que o deputado José Luiz de Almeida Nogueira interpôs ao Presidente da Província. 0 recurso versava sobre a "indevida inscrição dos nomes de alguns cidadãos e da omissão dos de outros, na lista geral de jurados deste termo do Bananal, formada pela respectiva junta revisora do alistamento". Com base nos artigos 101 e 102 da lei de 3 de dezembro e no artigo 234 do regulamento de 31 de janeiro, além do aviso de 14 de agosto de 1843 e do aviso de 10 de maio de 1869, o deputado conservador argumentava que a junta revisora, "ilegalmente constituída (...) organizou uma lista que por certo não satisfaz[ia] os interesses da justiça". 0 deputado apresentou, então, uma lista com 46 nomes que foram "arbitrariamente omitidos na lista apurada pela junta revisora" e solicitou a exclusão de outros nomes, alguns por falta de idade legal e por falta de renda legal, outros por não residirem no termo de Bananal, outros tantos por não serem elegíveis e, por fim, três nomes por estarem pronunciados. Sugeriu Almeida Nogueira que o Presidente da Província determinasse que a qualificação 
Correio Paulistano. 17/02/1880. Edição 6968. pp. 1-2. 0 recurso está datado de 7 de fevereiro de 1880 e cita outros artigos da lei de 3 de dezembro e do Regulamento de 31 de janeiro.

17

Correio Paulistano. 23/03/1880. Edição 6998. p. 2. Datado do Palácio do Governo de São Paulo de 20 de março de 1880 .

18

Correio Paulistano. 31/10/1879. Edição 6882. p. 2.

19

Correio Paulistano. 03/08/1882. Edição 7730. p. 2.

AESP. Ofícios diversos de Bananal: 1869-1891. Caixa 35. Ordem 829. Pasta 3. Doc. 65-A.

21

0 que significa dizer que o delegado Nogueira Cobra foi nomeado momentos depois da ascensão ao poder do Gabinete liberal comandado pelo Visconde de Sinimbu, em 5 de janeiro de 1878.

22

Correio Paulistano. 28/10/1881. Edição 7469. p. 1. Almeida Nogueira era o candidato conservador do $3^{\circ}$ Distrito à Assembleia Geral Legislativa. dos jurados do ano de 1879 fosse mantida no ano de 1880, em virtude das nulidades na sua elaboração, todas elas previstas na lei de 3 de dezembro de 1841 em seu artigo 28 e no artigo 225 do Regulamento de 31 de janeiro de $1842^{16}$. 0 recurso saiu vitorioso. 0 Presidente da Província, dr. Laurindo Abelardo de Brito, apesar de liberal, declarou "nula a qualificação de jurados do termo do Bananal" e atestou que deveria vigorar a qualificação do ano anterior "enquanto outra não for feita"17.

Os desmandos da "polícia liberal" foram alvo constante dos conservadores e Hipólito da Rocha Trigueirinho foi um dos alvos da reação desse grupo no final de 1879. 0 Correio Paulistano reproduziu em sua edição de 31 de outubro notícias do Monitor Paulista e do Echo Bananalense sobre os abusos desse Delegado. Segundo o primeiro órgão de imprensa (que pertencia, deve-se sublinhar, a Almeida Nogueira), a polícia procurava executar seus objetivos de "trucidar os adversários do governo" agindo de modo abusivo. Uma das vítimas dos excessos teria sido o "votante conservador" Olympio Leite da Costa, espancado e preso na casa de negócio de Leopoldino de Magahães ${ }^{18}$.

Igualmente, o liberal Boaventura Thurler, como suplente do subdelegado, era acusado de exercer uma série de arbitrariedades. Um desses abusos deu-se no dia 29 de julho de 1882 com a prisão do sr. Mangini, redator do Echo Bananalense. Supostamente, a prisão ocorrera por estar ébrio o redator. Para atestar a inocência do preso, o corpo de delito foi feito pelo doutor Luiz Antônio Nogueira, liberal, e pelo doutor José Joaquim de Azevedo Brandão, conservador. Em casos como esses, era necessário, para assegurar a imparcialidade, que o atestado fosse emitido por pelo menos um partidário aliado ${ }^{19}$.

No ano anterior à prisão do redator do Echo Bananalense, em outubro de 1881, os conservadores ainda reclamavam das ações e ameaças do comendador Antônio José Nogueira, demonstrando que as rivalidades entre esses dois grupos locais eram constantes. 0 Barão de Joatinga, do Partido Conservador, solicitava "providências diretas" para a cidade de Bananal ao Senador Florêncio Carlos de Abreu. A ação de Nogueira era similar à descrita anteriormente. 0 comendador agia difundindo o terror, dirigindose ao centro da cidade com capangas armados e agindo com aliados no Poder Judiciário loca ${ }^{20}$. Por ocasião da proximidade das eleições, Almeida Nogueira reclamava contra o delegado de polícia, tenente-coronel Joaquim Silverio Nogueira Cobra, "nomeado para esse cargo logo no princípio da situação política"21. Nogueira Cobra assumia pela quarta vez a jurisdição com o intuito de comandar as eleições. Em todas as outras, segundo Almeida Nogueira, ocorreram desordens e violências, sendo que na última vez, às vésperas da eleição de $1^{\circ}$ de julho de 1880 , Nogueira Cobra "chamou a si a vara" e "fez sua entrada na Cidade no dia da eleição à frente de um esquadrão de cavaleiros armados", entrando na igreja "de fitão transversal" e ordenando prisões. Temiam-se, por essas razões, desordens ${ }^{22}$.

0 temor e as advertências dos conservadores de Bananal eram justificados pela proximidade das eleições, que se realizariam no dia 31 de outubro. Essas eleições aconteceram sob a nova lei Saraiva, que instituiu o voto direto. Segundo Richard Graham, as eleições de 1881 foram "uma das mais honestas que o Brasil conhecera". Nesse sentido, entende-se porque, apesar das ameaças de violência e das tentativas de se dificultarem os trabalhos eleitorais, o deputado conservador pelo $3^{\circ}$ Distrito, José Luiz de Almeida Nogueira, foi eleito. A comemoração pela vitória do político 
GRAHAM, Richard. Op. Cit. p. 264. RAMOS, Agostinho. Op. Cit. p. 269-270; 388. Correio Paulistano. 04/12/1881. Edição 7501. p. 3. Correio Paulistano. 06/12/1881. Edição 7502. p. 1. Correio Paulistano. 24/12/1881. Edição 7514. p. 2. Correio Paulistano. 22/12/1881. Edição 7515. p. 2.
Correio Paulistano. 11/05/1884. Edição 8319. p. 1; Gazeta de Notícias. 08/05/1884. Edição 130. p. 1; Gazeta de Notícias. 12/05/1884. Edição 133. p. 2. bananalense aconteceu em Lorena e esse acontecimento serve de exemplo para se entender como o espaço de atuação desses líderes locais ultrapassava as barreiras de seus municípios. Em um jantar político que contou com a participação de eminentes correligionários, como o chefe do mesmo partido daquela cidade, o major Francisco de Assis e Oliveira Borges, foram oferecidos diversos "toasts [brindes] políticos" a vários membros do partido conservador, entre eles o dr. Antonio Prado ${ }^{23}$.

Como se vê, as décadas de 1870 e 1880, além de se caracterizarem pela crise da instituição escravista, foram marcadas pelas lutas políticas entre facções. Esse ambiente político conturbado pode ser dividido claramente em três momentos. 0 primeiro deles, de domínio conservador, vai da ascensão do Visconde de Itaboraí, em 16 de julho de 1868, até a chegada ao poder do Visconde de Sinimbu, liberal, em 5 de janeiro de 1878. Após quase dez anos de domínio conservador, os liberais reassumem o poder com Sinimbu, inaugurando, assim, o segundo momento, que duraria até a escolha do Barão de Cotegipe, em 20 de agosto de 1885. Por fim, a promoção de Cotegipe levaria novamente os conservadores ao poder. Esse novo momento conservador durou, praticamente, até o final do Império do Brasil. Essa periodização que segue a ordem dos gabinetes não é aleatória. Com ela verifica-se o predomínio político de determinada facção em Bananal em um dado momento e a violência política daí decorrente. Entende-se também a atuação do que se convém chamar de "polícia" - dos delegados, subdelegados etc. Os líderes de cada grupo serão, grosso modo, os seguintes: do lado liberal teremos, sempre, o comendador Nogueirinha auxiliado por uma infinidade de correligionários - dentre eles destacam-se o Doutor João Venâncio Alves de Macedo, cunhado do comendador, os filhos dele, Zoroastro Nogueira Alves de Macedo e Antônio de Macedo e o Doutor Francisco de Paula Ferreira; do lado conservador, distinguiam-se o Barão de Joatinga, seus filhos, Pedro Ramos Nogueira e José Luiz de Almeida Nogueira, e José de Magalhães Couto.

0 importante a salientar é que, na década de 1880, muitos liberais que estiveram envolvidos direta ou indiretamente nos embates políticos usaram, para atingir seus adversários, a plataforma abolicionista como estratégia de luta. Notícias a respeito do fantasma abolicionista rondando as fazendas e agindo diretamente entre os escravos podem ser encontradas na imprensa da época. Em maio de 1884, 31 escravos sequestrados pelo Banco do Brasil e que pertenciam ao espólio do finado coronel Marcos de Oliveira Arruda, antigo proprietário da Fazenda do Bom Sucesso, dirigiramse à guarda da cadeia reclamando dos maus tratos aplicados pelo depositário Alexandre José Pereira. Segundo a notícia, a população ficou alarmada e 0 artigo solicitava reforço do destacamento policial uma vez que mais de sete mil cativos trabalhavam em Bananal. Foram feitas averiguações e constatou-se que a reclamação de maus tratos não tinha fundamento, sendo possivel que os escravos tivessem sido "mal aconselhados por alguém"24. 0 momento histórico de crise da escravidão proporcionava notícias como essa. Não é possivel ter certeza se de fato os escravos da referida fazenda foram mesmo aliciados por agentes abolicionistas. Contudo, o alerta das autoridades e dos escravistas pode ter relação com os acontecimentos políticos e as rivalidades partidárias que estamos demonstrando. Uma modalidade especial de abolicionismo surgia nesse momento, relacionada às disputas partidárias e que se utilizava da plataforma antiescravista para atingir adversários políticos. Em 2 de outubro de 1884, o Correio Paulistano 
25

Sobre o "abolicionismo oficial", ver QUEIROZ, Jonas Marçal de. Op. Cit. p. 98. Vol. II. Queiroz analisou as lutas político-partidárias ocorridas na Província de São Paulo no periodo entre 1869 e 1889. Em seu trabalho, é possivel entender como esse momento histórico de crise da escravidão foi marcado pela instrumentalização política da revolta escrava. Sobre a notícia acerca do "abolicionismo oficial", ver Correio Paulistano. 02/10/1884. Edição 8437. p. 1. Os dois processos criminais envolvendo o liberto pelo Fundo de Emancipação Constantino e a escrava Paulina estão localizados no Museu Histórico e Pedagógico Major Dias Novais (doravante MMN), Cruzeiro/SP/ Caixa 48/ nº de ordem 989 e MMN/ Caixa $48 / n^{\circ}$ de ordem 1000. Para a análise desses dois processos criminais, ver SANTOS, Marco Aurélio dos. Geografia da escravidão na crise do Império: Bananal, 1850-1888. 2014. $281 \mathrm{f}$. Tese (Doutorado) - Faculdade de Filosofia, Letras e Ciências Humanas, Universidade de São Paulo, São Paulo, 2014. p. 163-179. Marcos de Oliveira Arruda e Braz Barbosa da Silva são identificados como conservadores no Correio Paulistano. 04/12/1878. Edição 6613. p. 2. Sobre o uso político das revoltas escravas, ver também o artigo de VITORINO, Artur José Renda \& SOUSA, Eliana Cristina Batista de. "0 pássaro e a sombra": instrumentalização das revoltas escravas pelos partidos políticos na província de São Paulo nas últimas décadas da escravidão. Estudos Históricos, Rio de Janeiro, v. 21, n. 42, p. 303-322, jul.-dez. de 2008.

26

QUEIROZ, Jonas Marçal de. op. cit. pp. 121-189. Vol I.

27

Gazeta de Notícias. 18/09/1884. Edição 262. p. 1. 28

0 casamento entre Antônio de Macedo e a filha do Comendador Nogueirinha ocorreu em 17 de janeiro de 1880, no oratório privado da Fazenda da Glória, de propriedade do chefe liberal. Gazeta de Notícias. 23/01/1880. Edição 23. p. 3. Ver as referências aos casamentos de importantes familias de Bananal em MELLO, Geraldo C. de. Os Almeidas e os Nogueiras de Bananal. São Paulo: Instituto Genealógico Brasileiro. s/d.

29

Conforme relato do advogado do Banco do Brasil, Antônio Caetano de Carvalho. Os dois processos envolvendo a Fazenda da Divisa serão analisados mais adiante. MMN/ Caixa 50/ n de ordem 1054 e também MMN/ Caixa 50/nº de ordem 1055. publicou notícia de um "comunicante" de Bananal dizendo que, em virtude da proximidade da eleição geral, os liberais no poder realizavam perseguições que induziam os escravos de proprietários conservadores a dirigirem-se às autoridades para reclamar contra os maus tratos recebidos. A ação era classificada de "abolicionismo oficial" porque estavam "à testa do movimento autoridades policiais e empregados públicos". Além do caso dos 31 escravos do conservador Marcos de Oliveira Arruda, à época já falecido, na pesquisa que se realizou com os processos criminais foi possivel identificar entre os anos de 1883 e 1884 apenas dois processos relativos a fuga de trabalhadores que se entregaram às autoridades reclamando de maus tratos. Os dois casos referem-se ao conservador dono da fazenda do Bom Retiro, Braz Barbosa da Silva. A amostragem é muito pequena e pode ser que a reclamação publicada no Correio Paulistano seja desse proprietário, uma vez que identificamos nesses dois processos o envolvimento de José Galdino da Rocha, correligionário liberal ${ }^{25}$. Apesar de não se ter uma amostragem significativa de processos criminais envolvendo escravos de proprietários conservadores que fugiam e se dirigiam ao centro da cidade para reclamar de maus tratos junto às autoridades, fica evidente que 0 abolicionismo entrara nas disputas partidárias do município como um elemento a mais para atacar adversários políticos. Contudo, à luz da pesquisa de Jonas Marçal de Queiroz, verifica-se uma diferença importante entre as disputas político-partidárias ocorridas em Campinas e em outros municípios do Oeste da Província de São Paulo e aquelas do município de Bananal, objeto deste artigo. Em Campinas, ao lado dos liberais e dos conservadores, os republicanos foram uma terceira força política importante nas lutas partidárias dentro do Clube da Lavoura e fora dele, conseguindo eleger deputados para a Assembleia Provincial. No periodo liberal que se inaugurou em 1878, liberais e republicanos foram duas grandes forças políticas que mediram forças nas eleições e em vários projetos referentes à mão de obra, imigração, entre outros assuntos. Segundo Queiroz, as rivalidades entre essas duas agremiações deveu-se à origem comum desses dois partidos (por exemplo, Campos Salles pertenceu ao Partido Liberal até a inversão partidária de 1868 e depois transferiu-se para o Partido Republicano), que disputavam basicamente o mesmo eleitorado, e à ação dos republicanos de disputar eleições em outros níveis ${ }^{26}$. Em Bananal, ao contrário, o Partido Republicano não foi uma força política atuante durante o Império.

Em 18 de setembro de 1884, mais um acontecimento aumentaria a tensão entre os partidários liberais e os conservadores. Nesse dia, a Gazeta de Notícias informava que Zoroastro Nogueira Alves de Macedo iria fundar na cidade de Bananal um "Club Abolicionista"27. A notícia, se lida de modo isolado, parece indicar que o abolicionismo estava fincando raizes nesse tradicional município escravista. Contudo, sabe-se que Zoroastro era um fervoroso liberal, muito próximo do comendador Nogueirinha. Seu pai, o Doutor João Venâncio Alves de Macedo, escravista e proprietário da fazenda da Divisa, era casado com Dona Maria Antônia Brazília Nogueira de Macedo, irmã de Nogueirinha. Portanto, Zoroastro era sobrinho do chefe do Partido Liberal de Bananal. Por sua vez, seu irmão, Antônio de Macedo, era casado com D. Auta da Gloria Nogueira de Macedo, filha do comendador Nogueirinha ${ }^{28}$. Como explicar a criação de um "Club Abolicionista" por um homem cujas ligações com um potentado local não o desvinculava de elos fortes com a escravidão? A pergunta é premente principalmente porque o pai de Zoroastro, proprietário da fazenda da Divisa, possuía cerca de 68 escravos $^{29}$. 
Gazeta de Notícias. 18/10/1884. Edição 292. p. 1. Assinado por Zé Fardão, um dos sonetos mencionados por Almeida Nogueira encontra-se na edição da Gazeta de 12 de outubro. Gazeta de Notícias. 12/10/1884. Edição 286. p. 2.
31

CONRAD, Robert. Op. Cit. p. 263-272.

MENDONÇA, Joseli Maria Nunes. Op. Cit p. 28-34.

32

Ver a lista de nomeações e exonerações no Correio Paulistano. 15/09/1885. Edição 8718. p. 2.

33

TOPLIN, Robert Brent. Op. Cit. p. 182.
Menos de um mês após a notícia sobre a criação de um "Club Abolicionista" em Bananal, Zoroastro de Macedo enviou uma carta à redação da Gazeta de Notícias informando a respeito de uma tentativa de assassinato da qual teria sido vítima. No mesmo número, o conservador José Luiz de Almeida Nogueira manifestou-se contra "sonetos impressos em estilo pornográfico" que estavam sendo espalhados pela cidade e que atingiam a ele e sua família. Acusando Zoroastro como conivente "no pensamento do autor ou autores desses escritos", Almeida Nogueira também relatou um entrevero entre Pedro Ramos Nogueira, seu irmão, e Zoroastro, e a negligência do já mencionado subdelegado Boaventura Thurler, "que recusou fazer efetiva a prisão em flagrante do delinquente [Zoroastro] e, mais ainda auxiliar o juiz de paz em desarmá-lo"30.

Esses ataques e movimentações ocorridos em 1884 não se relacionavam somente a rivalidades partidárias antigas e a rixas pessoais que se tornaram muito evidentes em Bananal por conta das disputas entre as parcialidades. Estavam relacionados também ao periodo pré-eleitoral que se aproximava. 0 acirramento dos ânimos nos momentos que antecediam às eleições foi uma constante no Império do Brasil. A eleição de $1^{\circ}$ de dezembro de 1884 confirmou a derrota dos liberais do $3^{\circ}$ Distrito, da qual Bananal fazia parte. Essa eleição ocorreu por conta dos debates em torno do projeto Dantas envolvendo a libertação dos escravos sexagenários. 0 projeto de emancipação de Dantas dividira o Partido Liberal nas províncias de Minas Gerais, São Paulo e Rio de Janeiro. Com uma Câmara dos Deputados marcadamente opositora, Dantas pediu que D. Pedro usasse seu poder constitucional para dissolver a Câmara e convocar novas eleições. 0 Imperador apoiou Dantas e o impacto imediato dessa medida foi um fortalecimento do Gabinete e de D. Pedro junto à frente abolicionista. Contudo, a nova Câmara eleita não era favorável aos projetos emancipacionistas que estavam sendo defendidos pelo Gabinete, sendo que muitos dos membros eleitos eram moderados ou conservadores nos assuntos relacionados à escravidão. 0 ano de 1885 marcou a queda do Gabinete Dantas, no inicio de maio, e expôs a divisão dos liberais. 0 novo Gabinete liderado por Saraiva reformulou o projeto de seu antecessor, sofreu intensas críticas dos abolicionistas e marcou o fim do período liberal ${ }^{31}$.

Lutas políticas e abolicionismo em Bananal: o período conservador (1885-1888)

A ascensão do Barão de Cotegipe em agosto de 1885 representou, no plano local, a nomeação de alguns conservadores históricos, dentre eles o Tenente Coronel Pedro Ramos Nogueira para delegado de polícia ${ }^{32}$. De acordo com Robert B. Toplin, a Lei Saraiva-Cotegipe [conhecida como Lei dos Sexagenários], aprovada em 28 de setembro de 1885, provocou um ponto de virada na estratégia abolicionista. A radicalização do movimento, com o recurso a atividades extralegais, seria, a partir de então, a marca principal de atuação de muitos grupos contrários à escravidão $0^{33}$. Em Bananal, 0 novo delegado iniciaria uma série de perseguições aos liberais. No período em que Pedro Ramos Nogueira esteve à frente das ações policiais, as lutas políticas adquiriram uma feição particular. Agora na oposição, alguns liberais usaram o abolicionismo para atacar os novos donos do poder. Um dos grandes embates que se pôde perceber nos anos de 1885-1887 foi entre Zoroastro e Pedro Ramos Nogueira. Novamente a imprensa seria um dos palcos de lutas desses grupos rivais. 
34

0 dr. João da Silva Carrão era cunhado do comendador Nogueirinha. Casado com D. Porcina Brasilia Nogueira, foi um importante político no Império do Brasil. Governou as províncias do Pará (1857-1858) e de São Paulo (1865-1866), e foi ministro da Fazenda no Gabinete de 12 de maio de 1865, cujo presidente do conselho foi - Marquês de Olinda. Esse breve histórico do senador Carrão mostra a influência e o poder dos partidários do comendador Antonio José Nogueira e as redes ligadas a esse fazendeiro. Ver MELLO, Geraldo C. de. Op. Cit. p. 47. As rivalidades entre Carrão e o Ministro da Agricultura Antonio Francisco de Paula e Sousa estão entre os motivos do enfraquecimento político do Marquês de Olinda e mostram as dissidências internas do Gabinete de 12 de maio. Ver a respeito IGLESIAS, Francisco. Vida política, 1848/1868. In: HOLANDA, Sérgio Buarque de. História Geral da Civilização Brasileira. 0 Brasil Monárquico: reações e transações, t. II, v. 3, Rio de Janeiro: Bertrand Brasil. 1987. p. 09-112

35

0 debate se estendeu por várias edições da Gazeta de Notícias entre meados de novembro e o início de dezembro. Ver Gazeta de Notícias. 12/11/1885. Edição 316. p. 1; Gazeta de Notícias. 14/11/1885. Edição 318. p. 1; Gazeta de Notícias. 15/11/1885. Edição 319. p. 2-3; Gazeta de Notícias. 22/11/1885. Edição 326. p. 3; Gazeta de Notícias. 23/11/1885. Edição 319. p. 2; Gazeta de Notícias. 04/12/1885. Edição 338. p. 3; Gazeta de Notícias. 06/12/1885. Edição 340. p. 2.

36

Gazeta da Tarde. 09/12/1885. Edição 283. p. 1.

37

A noticia sobre o atentado contra o liberal

Paulo Barbosa da Silva foi publicada também na Gazeta de Notícias através de telegrama enviado pela vítima. Ver Gazeta de Notícias. 08/12/1885. Edição 342. p. 1.
Zoroastro de Macedo denunciou via imprensa as perseguições que vinha sofrendo dos conservadores de Bananal. Em novembro de 1885, a Gazeta de Notícias publicou um telegrama dele em que dizia que o delegado Pedro Ramos Nogueira invadiu a propriedade de seu pai, o dr. João Venâncio Alves de Macedo, com cerca de 40 homens armados, e apreendeu com violência os escravos dessa fazenda, sendo que um dos escravos pertencia ao senador Carrão $0^{34}$. José Luiz Nepomuceno e o advogado do Banco do Brasil, Antônio Caetano, contestaram essa versão na edição de 14 de novembro, afirmando que a apreensão acontecera sem violência e por ordem judicial. No mesmo número, publicava-se um telegrama de Zoroastro a respeito das violências praticadas em Bananal contra os liberais. Acusava-se nominalmente o delegado Pedro Ramos de impedir as reuniões dos abolicionistas na cidade ${ }^{35}$.

Em 9 de dezembro de 1885, o órgão abolicionista a Gazeta da Tarde publicava uma carta de Zoroastro de Macedo. A missiva, dirigida a José do Patrocínio, explicitava os conflitos políticos existentes em Bananal e deixava claro que Pedro Ramos Nogueira era um dos inimigos do abolicionismo. Nos termos de Zoroastro:

\footnotetext{
Meu distinto amigo Patrocínio. Abraço-te dando a grata notícia de ter libertado, no dia 2 do corrente, um escravo de nome Caetano, de 25 anos de idade, sem ônus algum. Na cidade de Bananal, onde como sabes é minha residência, preparam-se vinganças contra mim, que sou alvo de perseguições dos sanhudos conservadores. Não querem eles que se instale o "Club Abolicionista". Hei de o fazer ainda de estandarte da liberdade dos cativos. Não calculas o que se passa naquela cidade. Imagina os mais terriveis assaltos à segurança pública e individual, ataques de toda a natureza, e podes, sem receio de ser contestado, dizer que tudo isso se passa em pleno século XIX, naquela cidade, e que o autor de tantos desmandos é o delegado de polícia Pedro Ramos Nogueira. 0 governo é surdo e mudo a tantas reclamações feitas pelos liberais ${ }^{36}$.
}

Considerando as lutas políticas existentes em Bananal e a oposição de longa data entre as parcialidades, a expressão "sanhudos conservadores" e a última frase adquirem um sentido político que explicita a crise entre os dois grupos. 0 trecho informa que os liberais desta localidade - pelo menos uma parte importante deles - estavam usando a plataforma abolicionista para atacar os conservadores no poder. Além de expor de modo evidente 0 vínculo com José do Patrocínio e seu jornal abolicionista, Zoroastro exprimia seu espaço de atuação, informando que a luta política extrapolava os limites territoriais do município.

No mesmo número da Gazeta da Tarde, lia-se a respeito dos abusos e violências praticados pelo delegado de polícia. Dentre eles, encontravam-se a prisão ilegal do liberto Caetano - provavelmente o mesmo mencionado na missiva de Zoroastro - e a invasão da fazenda do liberal Paula Barbosa da Silva, com o espancamento do administrador da fazenda e o roubo de cinco escravos ${ }^{37}$. Tendo em vista as disputas partidárias que tinham como palco diversos veículos de imprensa, é muito difícil determinar a veracidade desses acontecimentos e analisar a realidade das ações perpetradas pelas autoridades contra os liberais. É possível considerar que, se os liberais estavam se valendo da plataforma abolicionista contra os conservadores, os donos do poder no momento em que o Gabinete do conservador Cotegipe governava agiam contra membros dessa facção e seus escravos, como se pode entrever da notícia envolvendo a invasão da fazenda de Barbosa da Silva. Outras hipóteses poderiam ser formuladas sobre esses incidentes 
38

Conforme petição assinada por Zoroastro Nogueira Alves de Macedo em 8 de julho de 1886. MMN/ Caixa 50/ nº de ordem 1046. Conforme também petição assinada por Francisco de Paula Aranha em 6 de agosto de 1886. MMN/ Caixa 50/ no de ordem 1056. Infelizmente não conseguimos descobrir qual era a relação entre Francisco de Paula Aranha e Zoroastro Nogueira Alves de Macedo.

39

Conforme petição assinada por Zoroastro Nogueira Alves de Macedo em 14 de julho de 1886. MMN/ Caixa 50/ nº de ordem 1049.

40

Conforme resposta ao ofício do juiz de direito, assinada por Pedro Ramos Nogueira em 15 de julho de 1886. narrados nos periódicos dessa época. De qualquer modo, o que se pode inferir é que um dos campos para se verificar a luta política foi a imprensa. 0 impacto dessas violências e abusos repetidos de modo intermitente em diversos jornais, independentemente da realidade dessas ações e dos possíveis exageros, refletiam um campo de luta amplo, que pressionava os agentes públicos na localidade, movimentava a opinião púbica e poderia servir de freio para abusos maiores e para o despotismo desmedido. A imprensa constituíase como veículo para a disseminação de ideias e projetos políticos, bem como campo de atuação de todos os agentes políticos da localidade.

Nessa época, Zoroastro assumira definitivamente 0 abolicionismo como forma de militância política. Quatro processos criminais, três deles envolvendo escravos, confirmam essa atuação. Zoroastro participou diretamente em três deles, sendo que não se pode negar seu vínculo com o outro processo criminal.

0 primeiro refere-se a uma ordem de habeas corpus que Zoroastro impetrou em favor de 35 libertos que se achavam "debaixo da pressão do cativeiro". Todos esses libertos foram escravos do Capitão Francisco Gonçalves Pereira. Segundo os argumentos de Zoroastro, todos teriam sido libertados por seu dono com a condição de prestarem serviços por sete anos exclusivamente ao Capitão Pereira. Com o falecimento dele, os bens foram sequestrados por Leite de Campos \& Cia., negociantes da Corte, incluindo os referidos escravos que foram enviados à Fazenda do Cantagalo, sendo que o depositário dos bens era Antônio Joaquim Gonçalves da Graça. Havia também em poder da viúva do Capitão Pereira mais 8 libertos, "sofrendo todos em sua liberdade, e constrangidos ao trabalho", totalizando 43 escravos. A petição relativa a esses oito libertos foi assinada por Francisco de Paula Aranha e iniciou-se em 6 de agosto, pouco menos de um mês depois da ação iniciada por Zoroastro ${ }^{38}$.

Seis dias depois de peticionar ao juiz de direito acerca dos 35 libertos, Zoroastro de Macedo dirigiu-se novamente à mesma autoridade para reclamar da prisão arbitrária e sem justificativas de seu irmão, Antônio Nogueira de Macedo. 0 autor dessa prisão teria sido o delegado de polícia Tenente Coronel Pedro Ramos Nogueira. Segundo Zoroastro, seu irmão "retirava-se tranquilamente para sua fazenda" quando se encontrou com a polícia que estava "adrede colocada na rua da Misericórdia". 0 mesmo teria sido "agredido e mutilado sem haver o menor motivo para tão grande atentado"39. 0 delegado de polícia disse em resposta que Antônio de Macedo havia sido preso por achar-se armado e fazendo desordens em frente à casa de negócios de José Antônio de Oliveira, no bairro do Lavapés. Dirigindo-se ao local com duas praças, Ramos Nogueira encontrou-se com Antônio de Macedo, que estava cavalgando, e este dirigiu-Ihe um gesto desrespeitoso. Ordenando-Ihe "em alta voz" a prisão, Macedo resistiu com um chicote que trazia, mas acabou sendo preso e levado à sala das audiências, onde continuou a proferir uma série de ofensas contra Pedro Ramos Nogueira ${ }^{40}$. A sentença do juiz Antônio Ferreira França considerou a detenção legal e solicitou que ele continuasse na prisão. 0 processo é curto e não se pode saber quanto tempo Antônio de Macedo ficou preso. Contudo, vista à luz dos acontecimentos políticos e das rivalidades partidárias, sem dúvida essa prisão representa uma vitória parcial de Pedro Ramos Nogueira.

A prisão do irmão de Zoroastro aconteceu após o início do processo envolvendo os libertos do Capitão Pereira. Nesse caso, malgrado as alegações em contrário de Leite de Campos \& Cia., o juiz Antônio Ferreira França 
TOPLIN, Robert Brent. Op. Cit. 1975. pp. 196-197. Sobre a lei de 1831 e as estratégias adotadas para burlar essa legislação, ver RODRIGUES, Jaime. 0 infame comércio: propostas e experiências no final do tráfico de africanos para o Brasil (1800-1850). Campinas: Ed. da UNICAMP/CECULT, 2000. favoreceu todos os ex-escravos. 0 juiz considerou como válida a liberdade concedida pelo senhor e apontou irregularidades na assinatura do contrato entre a Leite de Campos \& Cia e o Capitão Pereira e sua mulher. Além disso, sua sentença teve também uma orientação antiescravista uma vez que ele percebeu que vários dos pacientes eram libertos por lei. Conforme notou Robert Brent Toplin, o período entre 1886 e 1888 foi marcado por decisões judiciais que se opunham cada vez mais aos interesses dos proprietários escravistas, inclusive aquelas baseadas na legislação de 1831 que aboliu o tráfico de escravos e considerou livres os africanos introduzidos após essa época ${ }^{41}$. Nesse sentido, França alegou que Marcelina, Ignácio e Thomazia eram libertos por serem sexagenários. Os escravos Israel e Ignácio foram apresentados como Elias e Antonio mas negaram ter esses nomes. 0 detentor, Antônio Joaquim Gonçalves da Graça, confirmou que os referidos escravos chamavam-se, de fato, Israel e Ignácio e, como não havia nenhum escravo com esses nomes matriculados em virtude da lei de 28 de setembro de 1871, os dois foram considerados livres. 0 caso desses dois escravos permite que se faça o seguinte questionamento: será que a empresa Leite de Campos \& Cia. sabia que esses dois escravos não estavam matriculados e, prevendo que eles poderiam ser libertados por esse motivo, apresentaram os referidos escravos com o nome de dois cativos já mortos e que haviam sido efetivamente matriculados? A pergunta é pertinente e aponta para uma possivel tentativa de fraude. Esses dois escravos, quando qualificados, informaram que eram conhecidos por outros nomes e não por aqueles em que foram apresentados à Justiça. A sentença de França prossegue alegando que Generosa e Maria não foram igualmente matriculadas pela referida lei de 28 de setembro de 1871 e eram, portanto, libertas. Os escravos Anacleto, Bernardo, Bonifácio, Domingos, Henrique, Joaquina, Josefa, Pedro e Tobias eram todos africanos e "nascidos depois do ano de 1831". Tinham todos a idade de 40 anos, exceto o paciente Henrique que tinha 25 anos, quando foram matriculados em julho de 1872. Como "entraram no território do Brasil depois do ano de 1831", eram livres.

A sentença proferida pelo mesmo juiz para os oito libertos que estavam em poder da viúva do Capitão Pereira foi mais simples e objetiva. Dizia que o senhor desses escravos havia concedido a liberdade "com a cláusula de prestação de serviços por sete anos não sendo, porém, declarado a favor de quem foi estabelecida a dita cláusula, que por isso devia ser entendida a favor somente do libertante (...)". 0 cativeiro para os 43 ex-escravos era, portanto, ilegal e o "constrangimento" a que estavam submetidos deveria acabar.

0 caso em questão ultrapassou os limites da cidade de Bananal. A Gazeta da Tarde, por intermédio de seu correspondente, informava aos seus leitores em sua edição de 24 de agosto de 1886 que o juiz de direito havia concedido a ordem de habeas corpus a favor dos 43 libertos. Mais ainda, 0 mesmo correspondente comunicava a existência em Bananal de 700 sexagenários libertados por exigência da lei de 28 de setembro de 1885 e que ainda se encontravam em cativeiro ${ }^{42}$. 0 caso dos libertos do Capitão Pereira indica que era possivel que sexagenários continuassem sendo submetidos ao "constrangimento ilegal" da escravidão. Principal órgão da imprensa abolicionista e dirigido por José do Patrocínio desde a morte de seu fundador, Ferreira de Menezes, a Gazeta da Tarde admitia diversos abolicionistas como colaboradores, dentre eles André Rebouças e um correspondente em Bananal. Esse correspondente, apesar de não ser identificado, muito prova- 
43

Gazeta da Tarde. 13/09/1886. Edição 211. p. 2.

44

Sobre a Gazeta da Tarde e a atuação de José do Patrocinio neste órgão de imprensa, ver TOPLIN, Robert Brent. Op. Cit. p. 68-70. CONRAD, Robert. Op. Cit. p. 187-189. A lei n² 2.040 de 28 de setembro de 1871, conhecida como Lei Rio Branco ou Lei do Ventre Livre, dizia, em seu artigo 8 , parágrafo $2^{\circ}$, que "os escravos que, por culpa ou omissão dos interessados, não forem dados à matrícula até um ano depois do encerramento desta, serão por este fato considerados libertos". Eis o fundamento jurídico para libertar os escravos Israel, Ignácio, Generosa e Maria.

\section{5}

Conforme petição datada de 10 de agosto de 1886. MMN/ Caixa 50/ nº de ordem 1054 e também MMN/ Caixa 50/ nº de ordem 1055.

46

Conforme depoimento prestado em 16 de agosto de 1886. velmente era Zoroastro de Macedo. Tratado como "nosso amigo" em alguns números ${ }^{43}$, Zoroastro colocava-se, nesses anos finais da escravidão, como um dos agentes abolicionistas dessa localidade. Ele foi presença constante nas páginas desse periódico ${ }^{44}$.

Outro caso importante que manifesta as oposições entre as parcialidades na crise do escravismo em Bananal foi o que envolveu Ana e Caetano, pertencentes ao pai de Zoroastro, dr. João Venâncio Alves de Macedo. A fazenda desse escravista, denominada Divisa, e seus escravos foram sequestrados pelo Banco do Brasil em dezembro de 1880. Segundo Zoroastro de Macedo, Ana e Caetano estavam detidos ilegalmente nessa fazenda. Os dois estavam em poder de Francisco Ramos Nogueira e o peticionário solicitava novamente uma ordem de habeas corpus. Uma vez mais, tem-se um caso em que um proprietário rural enfrentava problemas financeiros, estando com seus bens hipotecados. A questão é que Zoroastro alegava que seu pai havia libertado Caetano e Ana. Os dois, porém, foram presos e enviados à fazenda da Divisa, constando que Ana teria sido colocada no tronco e castigada. Conforme Zoroastro, "ambos acha[va]m-se constrangidos em sua liberdade e sofrendo as durezas do cativeiro"45. Francisco Ramos Nogueira detinha em seu poder os referidos pacientes - assim eles são denominados no processo - por ser "depositário nomeado no processo do sequestro em que é sequestrante o Banco do Brasil e sequestrado o dr. João Venâncio Alves de Macedo e sua mulher"46. Nogueira disse ainda que o Juiz Municipal, Doutor Antônio Manoel de Freitas, foi quem o nomeou para depositário dos referidos bens. Quando prestou depoimento no dia 16 de agosto, Ana disse que fora presa no início do mês por dois soldados enquanto lavava roupa no ribeirão, sendo conduzida para a fazenda da Divisa. Quando questionada em poder de quem esteve desde o dia trinta e um de maio, data da sua carta de liberdade e o início do mês de agosto, quando foi presa, Ana respondeu que

esteve em casa de João Fragoso, para onde foi a mandado do Tenente Coronel Pedro Ramos Nogueira e com o fim de arranjar ela respondente uma casa onde se alugasse para servir, e de fato esteve alugada em casa de Juca Diniz, e depois esteve alugada em casa do negociante Romão, no serviço de quem estava quando foi presa; e que quando esteve alugada nessas duas casas esteve alugada como mulher livre e não como escrava: respondeu mais que na fazenda da "Divisa" onde atualmente tem estado, acha-se em poder do detentor Francisco Ramos Nogueira.

Caetano prestou depoimento no mesmo dia e disse que, desde sua alforria, tinha estado na fazenda da Divisa em poder de Francisco Ramos Nogueira. Caetano afirmou que sua carta de liberdade tinha sido entregue a ele por sua senhora, Dona Maria Antônia, tendo sido tomada pelo Tenente Coronel Pedro Ramos Nogueira

\footnotetext{
na ocasião em que ele respondente [esteve] aqui na Cidade, no dia três de dezembro para o fim de ser conduzido para a fazenda da 'Divisa", para onde de fato foi conduzido pelo detentor Nogueira, tendo ele respondente estado preso na cadeia durante dois dias antes de ir para a dita fazenda; e que o doutor Antônio Caetano disse a ele respondente que apesar de ter sido passada carta de liberdade a seu favor, por enquanto não podia gozar da liberdade e tinha de ir trabalhar na fazenda "Divisa".
}

0 processo criminal apresenta várias lutas sendo travadas pelos sujeitos envolvidos. Verificam-se as lutas dos escravos e dos abolicionistas contra a escravidão e também de dois grupos: de um lado, o Tenente 
47

Sobre a crise econômica que afetou a cafeicultura, ver STEIN, Stanley J. Grandeza e decadência do café no Vale do Paraiba - com referência especial ao município de Vassouras. São Paulo: Brasiliense, 1961. p. 255-299.

48

CONRAD, Robert. Op. Cit., p. 224-225.

MACHADO, Maria Helena. op. cit. p. 116-122.

49

CONRAD, Robert. Op. Cit., p. 162. Ver também a nota 23 na mesma página. Baseado em estudo feito sobre o mercado de escravos em Campinas, Robert W. Slenes encontrou "indícios (no movimento dos preços dos cativos segundo sexo e idade) que indicavam um comportamento econômico racional por parte da maioria dos compradores e vendedores, isto é, a vitalidade do mercado de escravos no oeste paulista nesse período refletiria não os vestígios de uma mentalidade atrasada e em vias de ser superada, mas a escolha cuidadosa e calculada de uma forma de trabalho que continuasse oferecendo boas possibilidades de lucro". SLENES, Robert W. Grandeza ou decadência? 0 mercado de escravos e a economia cafeeira da Província do Rio de Janeiro, 1850-1888. In: COSTA, Iraci Del Nero da. (org.) Brasil: história econômica e demográfica. São Paulo: Instituto de Pesquisas Econômicas, 1986. p. 106-107.
Coronel Pedro Ramos Nogueira, o depositário Francisco Ramos Nogueira, o Juiz Antônio Manuel de Freitas e o advogado do Banco do Brasil, Antônio Caetano de Oliveira Carvalho; de outro, Zoroastro de Macedo e o juiz Antônio Ferreira França, o mesmo do processo dos 43 libertos do Capitão Pereira. 0 envolvimento do delegado Pedro Ramos Nogueira é evidente nos depoimentos de Ana e Caetano e revela a ação desse conservador contra seus adversários. 0 processo não esclarece porque o Tenente Coronel mandou Ana para a casa de João Fragoso. Talvez Pedro Ramos quisesse vigiar os passos da liberta, impedindo-a de sair do município e facilitando sua recondução à fazenda da Divisa.

Fica evidente que, nesse momento histórico, a luta travada por Ana e Caetano por intermédio de Zoroastro se revestia de roupagens políticas. Para os renitentes defensores da escravidão, não se tratava somente de uma ordem de habeas corpus, mas sim de evitar que o abolicionismo abrisse precedentes jurídicos em Bananal. Por outro lado, a participação do advogado do Banco do Brasil permite supor que esse credor estava agindo ao lado do poder constituído para garantir os direitos de seu cliente diante da dívida do dr. João Venâncio e de sua mulher.

Por fim, não se pode furtar à coincidência nos acontecimentos aqui analisados: a notícia publicada pelo Correio Paulistano sobre os 31 escravos de Marcos de Oliveira Arruda, o caso envolvendo os 43 escravos libertados pelo Capitão Francisco Gonçalves Pereira e o processo de Caetano e Ana estão todos relacionados a fazendas hipotecadas, o que indica que a crise da escravidão foi, também, uma crise econômica. Aliada à situação nacional de desagregação do escravismo, essa situação econômica tornava-se um agravante ${ }^{47}$.

0 exemplo dos escravos de Marcos de Oliveira Arruda pode remeter para o perigo da ocorrência da "ação direta", comum nas fazendas cafeeiras do Oeste Paulista principalmente pela atuação dos caifases. Nessa região, os elos que ligavam cidades como Campinas, Amparo e Casa Branca à cidade de São Paulo e Santos indicavam a construção de uma rede ampla de atuação abolicionista que incentivava as fugas dos escravos. Do mesmo modo, a ameaça de insurreição e as denúncias de aliciamento de escravos conformavam um quadro preocupante para a manutenção da ordem no Oeste Paulista. Conforme notaram Robert Conrad e Maria Helena Machado, as notícias de inúmeras revoltas de escravos no Oeste Paulista em 1882 indicavam a ação de abolicionistas que trabalhavam clandestinamente. A existência de escravos politizados insurgindo-se contra a ordem escravista sugeria a ação de abolicionistas agindo no meio dos escravos ${ }^{48}$. A necessidade de mão de obra nessa área de expansão era tão premente que Conrad mostrou exemplos de fazendeiros em Mogi Mirim, Limeira e Tietê que, nos anos finais da escravidão, ainda pagavam alto para comprar escravos ou reaver fugitivos ${ }^{49}$. Em Bananal, a ação de Pedro Ramos Nogueira e de outros correligionários seus procurou evitar, a todo custo, tal estado de coisas. Já o abolicionista Zoroastro de Macedo utilizava-se de uma estratégia que se poderia denominar "abolicionismo judicial".

No caso envolvendo Caetano e Ana, a alegação do advogado do Banco do Brasil esclarece sobre o conteúdo da dívida hipotecária do pai de Zoroastro. A escritura de "dívida, obrigação e hipoteca" foi assinada na Corte , "nas Notas do Tabelião Mathias", no dia 24 de dezembro de 1880. A divida estava em 73 contos de réis em novembro de 1885 e, por conta do descumprimento das cláusulas do contrato hipotecário, o sequestro 
50

A tabela vigente é aquela contida no parágrafo $3^{\circ}$ da lei $n^{\circ} 3.270$, de 28 de setembro de 1885 , a conhecida lei dos sexagenários. Sobre as discussões em torno da elaboração desse parágrafo, ver MENDONÇA, Joseli Maria Nunes. Op. Cit., especialmente o capítulo 3, "A lei e a escravidão: o preço da liberdade". Robert W. Slenes escreveu sobre o colapso no mercado de escravos entre os anos de 1881 e 1883. Sem dúvida essa "quebra" influenciou nas discussões acerca do preço do escravo e contribuiu para a aprovação do referido parágrafo da lei de 1885 SLENES, Robert W. The Brazilian internal slave trade, 1850-1888: regional economies, slave experience, and the politics of a peculiar market. In: JOHNSON, Walter. The chattel principle: the internal slave trade in the Americas. New Haven \& London: Yale University Press. 2004. p. 357.

51

Gazeta da Tarde. 29/09/1886. Edição 223. p. 2. 52

O Paiz. 29/09/1886. Edição 270. p. 1. foi solicitado. Os bens envolviam a fazenda denominada "Divisa" e mais "quarenta escravos como acessórios". Dentre esses escravos, encontrava-se a escrava Ana, de cinquenta e dois anos de idade e casada com o escravo Domingos. Alega o advogado que "mais tarde apareceu o escravo Caetano, crioulo, de trinta e nove anos de idade", casado com a escrava Maximiana, "que já estava seqüestrada e posta em depósito, verificando ele declarante que o referido Caetano achava-se também na hipoteca". 0 advogado do Banco do Brasil, Antônio Caetano de Carvalho, afirmou ainda em defesa de seu cliente que 68 escravos haviam sido hipotecados, mas que na data do sequestro só existiam 48 cativos, "por terem falecidos dois e os mais terem sido libertos, uns pelo fundo de emancipação e outros por serem maiores de sessenta anos". Desses 48 escravos, somente 40 escravos haviam sido efetivamente sequestrados porque os devedores agiram para ocultar oito escravos "em lugar por ele declarante não sabido, fora do município". Entre esses escravos ocultados, encontrava-se Caetano, o que explica porque 0 dr. Antônio Caetano de Carvalho disse que ele havia sido encontrado "mais tarde" e remetido posteriormente para a fazenda da Divisa. Segundo sua alegação, a fazenda da Divisa era velha, pequena e de pouco rendimento, valendo no máximo vinte contos de réis. Os escravos, pela tabela vigente ${ }^{50}$, valiam mais ou menos vinte e seis contos de réis. Portanto, os números mostravam que os devedores achavam-se "insolváveis" (sic), isso porque eles não possuiam "outros bens fora da hipoteca que possam completar o pagamento; assim sendo, não podia[m] confiar a liberdade como conferiram sob pretexto dos bens hipotecados chegarem para o pagamento". Portanto, as alforrias que, alega o dr. Carvalho, foram concedidas por Zoroastro, eram "nulas e sem efeito".

Ana e Caetano eram escravos casados. Infelizmente não foi possivel saber por que os dois foram libertados e seus respectivos cônjuges não conseguiram a carta de alforria. Mas foi possivel saber que Ana e Caetano foram beneficiados por uma decisão favorável do juiz Antônio Ferreira França, que julgou "ilegal o constrangimento" sofrido pelos dois pacientes "em sua liberdade, não devendo estar na fazenda 'Divisa' sujeitos ao regime da escravidão". Os credores, por sua vez, apelaram para o Tribunal da Relação de São Paulo, que revogou a decisão do Juiz de Direito em favor de Ana e Caetano, "visto terem sido incorporados na hipoteca feita ao Banco do Brasil da fazenda da Divisa".

Nas disputas em torno da liberdade de Ana e Caetano, pouco se sabe sobre as opiniões que os supostos libertos teriam da situação que estavam vivendo. Contudo, é possivel concluir que eles foram as maiores vítimas dessa luta política em torno da abolição da escravatura. Na Gazeta da Tarde de 29 de setembro de 1886, Zoroastro de Macedo informou à redação que a liberta Ana, logo após conseguir a ordem de habeas corpus, "foi para a fazenda da Divisa, colocada num tronco onde recebeu 150 açoites!...". E complementou: "neste lugar está tudo anarquizado. Única garantia é o dr. França, juiz de direito"51. O Paiz também publicou a carta de Zoroastro, perguntando: "serão ainda os flagícios (sic) legais a que se referiu o Sr. Presidente do conselho quando aludiu aos assassinatos da Paraiba do Sul?"52. 0 evento de Paraiba do Sul refere-se à punição de 300 açoites proferida por decisão judicial para quatro escravos, provocando a morte de dois deles. Segundo Robert Conrad, a discussão do evento de Paraíba do Sul por Joaquim Nabuco em $O$ Paiz e a publicação do episódio em outros jornais interferiu nos debates parlamentares e provocou a abolição do açoite, em 
CONRAD, Robert. Op. Cit., pp. 287-289. Ver também TOPLIN, Robert Brent. Op. Cit., pp. 198-201. Como um Gabinete conservador e um Parlamento igualmente avesso às reformas favoráveis à solução do problema da escravidão puderam votar uma lei abolindo a pena de açoite? Mais ainda: como o próprio Barão de Cotegipe, notadamente contrário a qualquer tipo de reforma envolvendo a escravidão, pôde apoiar essa lei? Jeffrey D. Needell procurou responder a essas contradições argumentando que a aprovação da referida lei foi uma consequência da crise política que o Gabinete de Cotegipe enfrentava. Nessa crise, Manuel Pinto de Sousa Dantas teve uma participação destacada na oposição a Cotegipe no Senado e na exposição das contradições desse politico nas questões que remetiam ainda à aprovação da Lei dos Sexagenários. A crise foi tão séria que ameaçou a existência do Gabinete. Cotegipe, para reafirmar seu apoio político e enfraquecer a oposição, que recebia suporte do movimento abolicionista, avalizou a reforma. Além disso, a lei referia-se apenas à abolição dos açoites pelas autoridades públicas e, como o próprio Cotegipe declarou, "(...) não se vá inferir que os escravos não estejam sujeitos aos castigos moderados que podem receber de seu senhor assim como do pai os recebe o filho, e de seus mestres o discípulo". Após sua aprovação, a lei desferiu mais um golpe contra a escravidão, devido à leitura que os sujeitos da época fizeram a respeito do fim da pena de açoites. Para o autor, "this one incident indicates a larger truth, for it reveals how parliamentary struggle, the Abolitionist movement, and the resistance of the captives interacted". Ver NEEDELL, Jeffrey D. Politics, Parliament, and the Penalty of the lash: The Significance of the End of Flogging in 1886. Almanack: revista eletrônica semestral. Guarulhos: UNIFESP, n. 4, p. 91-100, nov. de 2012. Disponivel em: <http://www.almanack.unifesp. br/index.php/almanack/article/view/838>. Acesso em: 13 jan. 2013.

54

TOPLIN, Robert Brent. op. cit. p. 68-69.

55

Gazeta de Notícias. 17/07/1886. Edição 198. p. 1. Gazeta de Notícias. 18/07/1886. Edição 199. p. 1. meados de outubro de 1886, malgrado o conservadorismo do Gabinete do Barão de Cotegipe e da Câmara, avessos às reformas relacionadas ao trabalho escravo ${ }^{53}$.

A missiva de Zoroastro foi publicada cerca de um mês após a decisão do Tribunal da Relação de São Paulo, não sendo possivel saber se a punição de 150 açoites relatada por Zoroastro efetivamente aconteceu ou se a informação fazia parte do jogo político relacionado às lutas abolicionistas. Caso tenha acontecido, a punição teria ocorrido após a decisão de França (16 de agosto) ou do acórdão do Tribunal da Relação (31 de agosto)? Ou teria acontecido quando ela foi presa, colocada no tronco e castigada, conforme se pôde ler em seu depoimento? De qualquer modo, Zoroastro explicitava que a luta abolicionista nacional havia entrado nos limites territoriais do município e se tornado de fato uma luta local. Isso, com certeza, preocupava os escravistas mais empedernidos de Bananal. Para Robert Toplin, a Gazeta da Tarde foi o periódico abolicionista de maior influência na década de 1880 e a virulência antiescravista desse jornal aumentou quando José do Patrocínio assumiu seu controle ${ }^{54}$. Por mais que os defensores da escravidão agissem na localidade para manter a ordem e o controle da situação, garantindo a permanência da mão de obra escravizada nas fazendas e efetuando rondas para promover a fiscalização e o controle da mobilidade dos escravos, a situação estava caminhando para o descontrole.

Nos anos de 1886 e 1887, as notícias veiculadas pelos jornais, principalmente a Gazeta da Tarde, a Gazeta de Notícias e o 0 Paiz, são muito semelhantes às dos anos anteriores. É comum ler sobre as lutas políticas e o tema do abolicionismo, com as perseguições e violências sendo associadas à rivalidade entre liberais e conservadores. Notícias simples e que aparentemente não teriam relevância analítica para o historiador adquirem, se contextualizadas, forte viés político. Assim, por exemplo, a Gazeta de Notícias publicou em 18 de julho de 1886 um relato sobre uma nova prisão de Antônio de Macedo, por ter sido acusado de fazer desordens, estar armado e agredir, no ato da prisão, a autoridade. 0 habeas corpus requerido foi-lhe negado. Ora, sabe-se que Antônio de Macedo era irmão de Zoroastro. $\mathrm{Na}$ edição seguinte, Zoroastro pronunciou-se dizendo que requereu corpo de delito em seu irmão, "o liberal Antônio de Macedo"55 e sentenciou: "continua a reinar grande agitação". Antepor o termo "liberal" ao nome da vítima significa introduzir um conteúdo político a um evento que poderia ser visto, se lido de modo descontextualizado, como apenas uma prisão de um desordeiro. A compreensão das notícias nesses termos permite verificar a ocorrência de lutas políticas nas localidades. Não se trata de negar o fato em si, ou seja, a possivel desordem que o preso pudesse estar fazendo e que justificaria, dessa maneira, sua prisão. Mas deve-se considerar que o espaço de luta política e a amplitude dessas notícias, veiculadas em periódicos na Corte, movimentavam a opinião pública e repercutiam em diversos meios.

0 final de 1887 e 0 início de 1888 provaram para muitos defensores da escravidão que a instituição estava com os dias contados. Libertações condicionais em massa aconteciam por toda a parte e eram exemplos da desagregação completa. Políticos importantes que em um passado recente advogaram a causa pró-escravista agora defendiam a abolição. Vários outros acontecimentos como as fugas em massa das fazendas, a agitação dos abolicionistas e a oposição dos militares provocavam crises políticas no governo imperial. A situação nacional de crise fazia muitos proprietários de escravos pensarem a respeito dos possíveis prejuízos com a abolição 
57

Sobre a conversão de Antonio Prado à causa abolicionista, ver CONRAD, Robert. Op. Cit. pp. 303-304 e TOPLIN, Robert Brent. Op. Cit. pp. 229232. A reportagem citada encontra-se em Gazeta de Notícias. 15/12/1887. Edição 349. p. 2.

58

Correio Paulistano. 17/01/1888. Edição 9414. p. 2. Sobre o movimento de migração para as áreas de fronteira, inclusive com referência à grande produtividade do município de São Simão, ver MARQUESE, Rafael de Bivar. Capitalismo, escravidão e a economia cafeeira do Brasil no longo século XIX. Saeculum - Revista de História, n.29, jul./dez. 2013. p. 289-321.

59

Correio Paulistano. 09/03/1888. Edição 9457. p. 2.

60

Gazeta de Notícias. 16/03/1888. Edição 76. p. 2.

Correio Paulistano. 05/05/1888. Edição 9504.

p. 2.

e dos perigos de "anarquia e de ameaça de revolução social"56. A mudança era visível por toda a parte. É nesse quadro nacional de instabilidade social e política que se pode entender a notícia do dia 15 de dezembro de 1887, publicada pela Gazeta de Notícias. Nesse dia, o jornal informou que a Sra. D. Catharina Joaquina dos Santos e seu irmão, o Sr. Francisco Carvalho dos Santos, ambos de Bananal, "libertaram todos os seus escravos com a condição de lhes prestarem serviços até 31 de dezembro de 1888, e desistiram com a mesma condição dos serviços dos ingênuos e sexagenários, cujo número se eleva[va] a mais de quarenta". Além disso, a notícia indicava a atuação de outros abolicionistas, chamados de "emancipadores", no município, como o Sr. Manuel Joaquim Rodrigues de Carvalho Junior, e informava que se acentuava o "movimento em favor dos escravizados, no sentido indicado pelo ilustre conselheiro Antonio Prado"57. Esse movimento de D. Catharina era generalizado em diversas partes.

Em janeiro de 1888, Pedro Ramos Nogueira encontrava-se na capital da Província de São Paulo. Também estava na capital Pedro Ramos Nogueira de Gouvêa e sua família, que se mudavam para São Simã $0^{58}$. Em março, 0 Barão de Ribeiro Barbosa recebia autorização do ministério da Agricultura para "introduzir na fazenda de sua propriedade, denominada Ponto Alegre, situada no município do Bananal, 12 famílias de agricultores do norte da Itália ou Tyrol"59. As notícias informam que as mudanças se processavam de diversas maneiras. Escravistas que se mudavam para áreas de fronteira devido ao colapso da produção cafeeira em seus municípios de origem e outros que já planejavam a recepção de imigrantes em suas propriedades. Essas notícias contrastavam ainda com o reacionarismo das autoridades policiais, provavelmente para garantir os interesses de proprietários que ainda se agarravam à escravidão, como se pode ler na Gazeta de Notícias de 16 de março que, em tom exclamativo, publicou que "no Bananal de S. Paulo, a 12 do corrente, foram presos cinco escravos e um deles amarrado pela polícia. Parece impossível que ainda haja destas cenas, e em S. Paulo!"60. A curta notícia demonstra ainda os embates em torno da escravidão e da manutenção da ordem em um contexto generalizado de transformações.

Às vésperas do 13 de maio, o Correio Paulistano publicou trechos do Relatório do Presidente de Província, Rodrigues Alves, que tratava dos núcleos coloniais. Mencionando diversos municípios do Vale cafeeiro como os de Bananal e Cruzeiro, o Relatório definiu esses núcleos como "centros de trabalhadores-proprietários, ou foco de atração de imigrantes, como se diz vulgarmente". Mas, esclareceu, esses núcleos coloniais não se destinariam exclusivamente aos imigrantes, sendo que os trabalhadores nacionais deveriam ser igualmente contemplados. Nesse sentido, é bastante significativa a sugestão de mudança dos espaços agrários das fazendas que se pode entrever nesse Relatório, tendo em vista o contexto de crise do trabalho escravo. Diz o documento que "é tempo de cuidar o fazendeiro no desmembramento de sua propriedade, pela divisão em lotes, para serem vendidos aos pequenos cultivadores. Darão assim valor à parte que reservarem para si, e terão à mão trabalhadores para auxiliarem-nos no cultivo de sua lavoura"61. Essa reconfiguração dos espaços agrários das fazendas de café, anunciando um novo contexto que se avizinhava, já foi sugerida por João Luis Ribeiro Fragoso em seu trabalho sobre Paraíba do Sul. Nos inventários pós-1888, esse autor verificou que as senzalas estavam dando lugar às "casas de colonos" e que os pastos cada vez mais ocupavam o lugar dos cafezais. Segundo esse autor, a formação da pecuária em municípios como os 
FRAG0S0, João Luis Ribeiro. Sistemas agrários em Paraiba do Sul (1850-1920): um estudo de relações não capitalistas de produção. 1983. 182 f. Dissertação (Mestrado em História) - Instituto de Filosofia e Ciências Sociais, Universidade Federal do Rio de Janeiro, Rio de Janeiro, 1983. p. $140-155$

63

Como no exemplo citado por MATTOS, Hebe Maria. Das cores do silêncio: os significados da liberdade no Sudeste escravista - Brasil, século XIX. Rio de Janeiro: Nova Fronteira, 1998. p. 224-225.

64

Ler, por exemplo, a nota de repúdio ao assassinato publicada no Correio Paulistano. 22/07/1888. Edição 9566. p. 2.Ver também o relatório do chefe de polícia, José Joaquim Cardoso de Mello Junior, publicado no Correio Paulistano. 30/08/1888. Edição 9598. p. 1. Ver também Gazeta de Notícias. 15/11/1888. Edição 201. p. 1. Gazeta de Notícias. 15/11/1888. Edição 203. p. 3.

65

Conforme telegrama enviado à Gazeta de Notícias. 17/09/1888. Edição 260. p. 2. Neste telegrama, apresenta-se breve histórico da familia Macedo. Antônio de Macedo, o outro acusado pelo crime e ainda foragido, havia confessado em carta ser o único autor dos assassinatos.

66

Gazeta de Notícias. 15/11/1888. Edição 203. p. 1. de Paraiba do Sul (e também de Bananal) não aconteceu de forma abrupta. As características do sistema agrário vigente na agricultura de exportação fez aumentar a quantidade de terras em capim, que precederam a prática da pecuária ${ }^{62}$. A persistência do quadrado, porém sem a necessidade de fechadura, e o aproveitamento das senzalas pelos colonos já indicavam a destruição em grande escala das moradias dos escravos ${ }^{63}$. Das várias consequências dessa crise nacional que levou à Lei Áurea, pode-se mencionar a necessidade de uma reconfiguração dos espaços agrários das fazendas cafeeiras, com vistas à acomodação de novas relações de trabalho.

A lei de 13 de maio foi resultado de um longo processo de desagregação e de intensos combates envolvendo diversos sujeitos, com interesses e soluções variados. A escravidão acabou com a Lei Áurea, mas um dos temas do período escravista que ultrapassaram os limites temporais do 13 de maio foi o das disputas partidárias em Bananal. 0 resultado das rivalidades entre os sujeitos anteriormente mencionados teve um de seus momentos trágicos no dia 19 de julho de 1888. Nesse dia, tiros disparados de uma das janelas da fazenda da Gloria, pertencente ao chefe do Partido Liberal de Bananal, o comendador Nogueirinha, mataram o chefe do Partido Conservador, Pedro Ramos Nogueira, e o Dr. José Caetano Horta Barbosa. 0 crime, de natureza política, teve ampla repercussão, envolveu autoridades das Províncias do Rio de Janeiro e de São Paulo, foi noticiado em diversos jornais e reverberou no Parlamento brasileiro ${ }^{64}$. Antônio Nogueira de Macedo, o irmão de Zoroastro de Macedo, e o Comendador Nogueirinha foram pronunciados nas penas dos artigos 192 e 193 do Código Criminal. Apresentado pela Gazeta de Notícias como típico chefão local, o comendador Nogueirinha foi retratado como sendo um homem baixo, "de fisionomia animada e inteligente", olhar vivo e com barbas longas e grisalhas, paralítico do lado esquerdo e com 61 anos à época do crime ${ }^{65}$.

As lutas políticas em Bananal revelam que a identidade de classe dos proprietários rurais desse importante município cafeeiro, quando iluminada pelas trajetórias desses sujeitos, não pode ser considerada como algo monolítico, separado das experiências políticas que eles vivenciaram na localidade. Além disso, as disputas entre as parcialidades e o uso do abolicionismo como estratégia de luta política contra os conservadores expressaram a crise dessa classe. A Gazeta de Notícias publicou, em sua coluna intitulada Chroniqueta, uma avaliação dos motivos do assassinato. Segundo o artigo, a designação do coronel Pedro Ramos Nogueira para a Guarda Nacional teria sido a "gota d'água" para a ocorrência do assassinato. A expressão "gota d'água" pressupõe que, antes de o copo ficar cheio, muitos rancores e animosidades foram sendo gestados ao longo de anos. A coluna da Gazeta de Notícias resume: "a guarda nacional é uma das fanfreluches da pequena política das localidades como são fanfreluches os títulos nobiliários, as condecorações, a vice-presidência das províncias, os lugares de substituto de juiz municipal, o juizado de paz, a vereança etc"66. "Fanfreluche" significa adorno frivolo e de pouco valor. No final do Império, poderia ser comum criticar esses cargos. Mas a importância dessas frivolidades para a vida política das localidades no Império do Brasil foi muito grande. Ela está diretamente associada à violência política e à busca de prestígio baseada em uma combinação de elementos que vão desde as práticas clientelísticas que unem a vida das cidades à política imperial, dando força e representatividade simbólica aos chefes locais, até as buscas de manifestação explícita do poder desses mesmos poderosos. Nogueirinha faleceu na prisão, 
67

Gazeta de Notícias. 07/12/1888. Edição 341. p. 1.

68

GRAHAM, Richard. Op. Cit. p. 40. Ver também o capítulo 4, "0 Teatro das eleições".

69

BARRETO, Lima. Os bruzundangas. São Paulo: Ática, 1985. em São Paulo, no dia 6 de dezembro de 1888. Segundo perfil traçado pela Gazeta de Notícias, o comendador Antônio José Nogueira]

fora o chefe do partido liberal na cidade do Bananal por espaço de trinta anos, exercendo em todo município real influencia política. Ocupara todos os cargos de eleição popular, e quando o seu partido achava-se na governação do país era ele quem apontava o deputado provincial do distrito ou o candidato sobre quem deveriam recair os votos para a eleição geral. (...) Em política, porém, era mais do que intransigente, - arbitrário, violentíssimo. Durante o regime indireto [que vigorou até a reforma eleitoral de 1881], presidia as eleições no corpo da igreja matriz do Bananal, como juiz de paz, com o respectivo fitão traçado sobre a farda de oficial da guarda nacional (por esse tempo tinha o posto de major) - e o revólver à cintura, à mostra. Tinha a mão sobre a urna e nessa só deixava caírem os votos dos seus ${ }^{67}$.

Retrato transparente da atuação política de um potentado local no Brasil do século XIX. Como se vê, o dia das eleições era o momento ritualístico em que alguns sujeitos exibiam de modo claro suas posições dentro da sociedade. Por trás desse comportamento, estava todo um contexto político que moldava identidades coletivas e modulava, sem hiatos, a história local com a história da política do Império do Brasil. Como notou Richard Graham, a propriedade de grandes extensões de terra e de escravos "demonstrava sucesso e ajudava enormemente no séquito de uma pessoa, mas o recurso crucial continuava sendo a lealdade de outros". Graham sentencia, talvez com certo exagero, porém com acurado olhar sobre as práticas políticas no Império do Brasil, que "o tamanho da clientela era a medida de um homem"68. 0 prestígio de um homem relacionava-se com a clientela que ele conseguia arregimentar, com o aparato simbólico de títulos que ele podia alcançar e com a riqueza material que ele conseguia acumular. Daí vinha sua importância política como chefe local. Alguns anos depois da Proclamação da República, Lima Barreto reafirmou, em sua análise sobre a República dos Estados Unidos da Bruzundanga, o valor das fanfreluches para a prática política e o status social, mostrando que velhas práticas se perpetuavam em novos contextos políticos ${ }^{69}$.

\section{CONCLUSÃO}

Os casos narrados neste artigo permitem perceber uma apreensão espacial para o Estado Imperial, que conseguiu estender suas influências às municipalidades e que subjugou essas mesmas municipalidades às esferas do poder provincial e da Corte. Isso revelou uma malha de interesses que vinculavam o "local" ao "central", passando pelo nível provincial, demonstrando um "jogo de escalas" que marcou a atuação dos sujeitos com grande projeção política.

Desse modo, foi possivel perceber que o livro de Ilmar Rohloff de Mattos apresenta, em que pese a validade de sua tese, uma orientação verticalizada, de cima para baixo, do funcionamento do Estado Imperial. A tese de Mattos se completa com os trabalhos de Thomas Flory, Miriam Dolhnikoff e Maria de Fátima Silva Gouvêa, permitindo e entendimento do funcionamento da política no Império do Brasil como uma via de mão dupla, na qual os proprietários de escravos do município de Bananal - que participaram, sem nenhuma dúvida, do consenso estudado por IImar Mattos - agiu historicamente para construir articulações mais amplas e que vinculavam a fazenda à Província e à Corte (genericamente, o Conselho de Estado, o Senado, a Câmara, a Assembleia Provincial mas também os 
70

Para outros exemplos dessas articulações entre o "local" e o "central" ver SANTOS, Marco Aurélio dos. Op. Cit., p. 180-202.

71

Sobre a "direção saquarema" e o consenso que dai surgiu ver MATTOS, IImar Rohloff. Op.Cit., pp. 169-171. negociantes de escravos, os comissários etc.). Por outro lado, viu-se que o Estado Imperial conseguiu exercer sua influência no âmbito da localidade, especialmente com base na legislação que centralizou as nomeações dos agentes judiciários e policiais.

Em um contexto de normalidade institucional, o jogo político do Estado Imperial aconteceu com as variações partidárias executadas especialmente pelo Poder Moderador. Contudo, nas décadas finais da escravidão, os conflitos fratricidas entre famílias ou parcialidades após o período 1868-1871, aliado aos intensos questionamentos acerca da transição do trabalho escravo para o livre, expuseram um momento histórico de crise generalizada dos mecanismos jurídicos e constitucionais que embasavam o Estado Imperial.

Assim, existem fortes indícios para se inferir que a violência política e as rivalidades aqui relatadas eram decorrência (a) de uma característica muito particular do funcionamento do poder no Brasil e (b) do momento de crise política do período 1878-1888, potencializada pelo movimento abolicionista. Quanto ao primeiro item, o funcionamento desse poder fazia pender o prato da balança para o governo central e para o nível da Província. Desse modo, o debate político na localidade ultrapassava os limites do municipio e chegava às demais esferas do poder. Esse funcionamento do poder no Império do Brasil obrigou uma movimentação mais ampla principalmente dos potentados mais influentes politicamente. As disputas entre as parcialidades aqui narradas aconteceram dentro do arranjo institucional que foi construído com as reformas das décadas de 1830 e 1840 - especialmente o Ato Adicional, a Interpretação do Ato Adicional e a reforma do Código de Processo Criminal. Esse arranjo institucional forçou os potentados locais a atuarem para além do município, ampliando, igualmente, seu espaço de atuação ${ }^{70}$.

Nos conflitos aqui narrados, a lei de 3 de dezembro de 1841, um dos diplomas que fundamentaram a "direção saquarema"71, esteve presente ora como instrumento de ação e manifestação do poder pelo grupo dominante, ora como recurso para evitar o despotismo. A lei de 3 de dezembro foi um dos instrumentos para que os dois lados em disputa pudessem atacar e defender. Os proprietários de escravos, conservadores ou liberais, fossem eles situação ou oposição, atuaram no âmbito dessa legislação centralizadora do judiciário erigida pelos saquaremas. Além disso, como se pode ver da atuação dos liberais e conservadores, a política ultrapassou o âmbito da municipalidade e a Assembleia Provincial, a Presidência Provincial e as instâncias do governo central refletiram as tensões políticas internas do município. 0 espaço de atuação de muitos potentados da localidade e de seus representantes foi bastante amplo e não se restringiu à fazenda ou ao município.

Nesse sentido, o arranjo institucional construído a partir das décadas de 1830 e 1840 funcionou como ferramenta para que os grupos políticos atuassem na defesa de seus interesses e de suas plataformas políticas. Como se viu, os chefes políticos na localidade eram submetidos à máquina pública controlada a partir da Corte. Isso ficou bem evidente nos dois momentos delineados neste artigo: o período liberal (1878-1885), que agregou nomeações de liberais, e o momento conservador (1885-1888), que favoreceu designações de partidários dessa parcialidade. A preeminência, portanto, recaía para quem estava no poder central, para o Gabinete e o partido político de ocasião. 0 grupo partidário que assumia o poder no âmbito federal abria margem para que os partidários rivais nas localidades 
fossem isolados, enfraquecidos ou, quiçá, eliminados. Para tal empreendimento, o controle da máquina pública era fundamental. Assim, a facção apoiada pelo governo central garantia seu domínio. Por outro lado, os que estavam sendo afastados procuravam manter sua visibilidade e a oposição sempre encontrava seu espaço, especialmente no âmbito da política provincial e da imprensa. Por isso a eleição e seu corolário, a violência, eram uma das portas de entrada que ligava o "local" ao "central". 0 controle dos votos pelos partidários na localidade era importante para garantir vitórias eleitorais. Os grandes proprietários rurais controlavam seus eleitores através das ações clientelísticas, indicando-os para os cargos da máquina pública e cooptando-os em suas propriedades rurais. Mas era igualmente necessário ter o controle da mesa eleitoral ou obstar seus trabalhos. Por seu turno, o Gabinete de ocasião realizava uma onda de nomeações que garantia no plano local o domínio dos chefes políticos. Vários fatores acima indicados demonstram essa dominância do governo central e, em segundo plano, do nivel provincial, sobre a localidade. Uma das explicações que foram dadas para que Antônio José Nogueira participasse do assassinato de seu rival político, Pedro Ramos Nogueira, foi a nomeação desse último para a Guarda Nacional, função controlada pelo Ministro da Justiça. Outro fator que mostra a preeminência do governo central sobre o local estava na arena de luta política. Ela não se restringia à localidade, mas ultrapassava seus limites, sendo discutida no âmbito do governo provincial, na Assembleia, nos periódicos ou mesmo na Corte, chegando ao Parlamento. Outro exemplo estaria relacionado aos debates e ao jogo de versões e contraversões que se pôde perceber nos jornais de época. Era muito comum ler artigos endereçados ao Ministro da Justiça, ao Ministro do Império, ao Presidente de Província ou mesmo ao próprio Imperador, denunciando abusos e violências. Em que os signatários dessas mensagens, muitas vezes escondidos no anonimato, acreditavam? Talvez o efeito prático desses artigos endereçados a essas autoridades fosse muito pequeno, mas é possivel concluir que eles demonstravam que, por mais que a facção no poder usasse da violência e da intimidação e que ambas fizessem parte do funcionamento dos grupos que estavam no poder, havia um limite tolerável para a ação dos chefes locais que usavam desses recursos. 0 absolutismo irrefreável, com todos os seus corolários, era algo que não se esperava. Talvez Antônio José Nogueira estivesse muito confiante na impunidade para participar do assassinato de um adversário político. Mas ele foi preso e morreu na prisão, em São Paulo, momentos antes de se ver obrigado a ir para Bananal para responder ao Júri. Havia, de fato, um limite e os liberais, em 11 de agosto de 1879, quase excederam as balizas toleráveis das disputas políticas: a tentativa de assassinato (ou agressão física) de um líder opositor local dizia que o limite tolerável de disputas partidárias estava prestes a ser atingido; 0 assassinato, em plena luz do dia, significou que esse limite foi ultrapassado. Além disso, esses artigos de jornais endereçados às autoridades do Império demonstram que o espaço de atuação dos proprietários das localidades era obrigatoriamente mais amplo devido a vários fatores como a subordinação dos municípios ao governo provincial, uma das decorrências do Ato Adicional de 1834, e as redes de relacionamentos construídas pelos grandes proprietários que extrapolavam os limites do município.

Considerar o espaço de atuação dos proprietários rurais da localidade permite entender o funcionamento do poder no Império do Brasil e a vinculação dos potentados locais com os níveis do governo provincial e do 
governo central. Permite entender, igualmente, a dominação dos potentados locais sobre o conjunto de escravos e homens livres deles dependentes. Esse jogo de escalas é de fundamental importância para aqueles pesquisadores que pretendem estudar um determinado município não apenas como um "estudo de caso" e desejam compreendê-lo inseridos em uma realidade política mais ampla.

\section{REFERÊNCIAS BIBLIOGRÁFICAS}

Fontes Manuscritas

MUSEU HISTÓRICO E PEDAGÓGICO MAJOR NOVAES - CRUZEIRO/SP PROCESSOS CRIMINAIS

Localização: Caixa 48/ n ${ }^{\circ}$ de ordem 989. Natureza da ocorrência: Castigo do feitor em Constantino que havia sido libertado pelo Fundo de Emancipação. Data da ocorrência: 3 de julho de 1883.

Localização: Caixa 48/ n de ordem 1000. Natureza da ocorrência: Fuga da escrava Paulina, pertencente ao Dr. Braz Barbosa da Silva. Data da ocorrência: 20 de março de 1884.

Localização: Caixa 50/ nº de ordem 1056 e Caixa 51/ nº de ordem 1057. Natureza da ocorrência: Habeas corpus (libertos que se achavam debaixo da pressão do cativeiro). Data da ocorrência: 06 de agosto de 1886

Localização: Caixa 50/ nº de ordem 1054 e Caixa 50/ no de ordem 1055. Natureza da ocorrência: Habeas corpus. (Caetano e Ana, escravos do Dr. João Venâncio Alves de Macedo). Data da ocorrência: 10 de agosto de 1886.

Localização: Caixa 50/ no de ordem 1046. Natureza da ocorrência: ação de liberdade (vários libertos que se achavam debaixo da pressão do cativeiro). Data da ocorrência: 1886.

\section{ARQUIVO PÚBLICO DO ESTADO DE SÃO PAULO (AESP)}

Ofícios diversos de Bananal: 1869-1891. Caixa 35. Ordem 829. Pasta 3. Doc. 41 e 41-A.

Ofícios diversos de Bananal: 1869-1891. Caixa 35. Ordem 829. Pasta 3. Doc. 65-A.

\section{PERÍODICOS CONSULTADOS}

Correio Paulistano. 17/02/1878. Edição 6384; 13/08/1878. Edição 6525; 04/12/1878. Edição 6613; 09/03/1879. Edição 6689; 21/03/1879. Edição 6699; 13/08/1879. Edição 6816; 17/08/1879. Edição 6819; 24/08/1879. Edição 6825; 26/08/1879. Edição 6826; 27/08/1879. Edição 6827; 28/08/1879. Edição 6828; 29/08/1879. Edição 6829; 31/10/1879. Edição 6882; 23/01/1880. Edição 6949; 17/02/1880. Edição 6968; 23/03/1880. Edição 6998; 28/10/1881. Edição 7469; 04/12/1881. Edição 7501; 06/12/1881. Edição 7502; 24/12/1881. Edição 7514; 22/12/1881. Edição 7515; 03/08/1882. Edição 7730; 11/05/1884. Edição 8319; 02/10/1884. Edição 8437; 17/01/1888. Edição 9414; 09/03/1888. Edição 9457; 05/05/1888. Edição 9504; 22/07/1888. Edição 9566; 30/08/1888. Edição 9598.

Gazeta de Notícias. 17/08/1879. Edição 225; 08/05/1884. Edição 130; 12/05/1884. Edição 133; 18/09/1884. Edição 262; 18/10/1884. Edição 292; 12/10/1884. Edição 286; 12/11/1885. Edição 316; 
14/11/1885. Edição 318; 15/11/1885. Edição 319; 22/11/1885.

Edição 326; 23/11/1885. Edição 319; 04/12/1885. Edição 338;

06/12/1885. Edição 340; 08/12/1885. Edição 342; 17/07/1886.

Edição 198; 18/07/1886. Edição 199; 15/12/1887. Edição 349;

16/03/1888. Edição 76; 15/11/1888. Edição 201; 15/11/1888. Edição

203; 17/09/1888. Edição 260; 15/11/1888. Edição 203; 07/12/1888.

Edição 341

O Mequetrefe. 20/08/1879. Ano 5. Número 180.

Gazeta da Tarde. 09/12/1885. Edição 283; 24/08/1886. Edição 193;

13/09/1886. Edição 211; 29/09/1886. Edição 223

O Paiz. 29/09/1886. Edição 270.

Bibliografia

AZEVEDO, Elciene. 0 direito dos escravos: lutas jurídicas e abolicionismo na província de São Paulo. Campinas: Ed. da Unicamp, 2010.

BARRETO, Lima. Os bruzundangas. São Paulo: Ática, 1985.

CARVALHO, José Murilo de. A construção da ordem: a elite política imperial/ Teatro de sombras: a política imperial. Rio de Janeiro:

Civilização Brasileira, 2008.

CONRAD, Robert. Os últimos anos da escravatura no Brasil: 1850-1888. Rio de Janeiro: Civilização Brasileira, 1978.

FRAGOSO, João Luís Ribeiro. Sistemas agrários em Paraiba do Sul (18501920): um estudo de relações não capitalistas de produção. 1983. 182 f. Dissertação (Mestrado em História) - Instituto de Filosofia e Ciências Sociais, Universidade Federal do Rio de Janeiro, Rio de Janeiro, 1983.

FLORY, Thomas. El juez de paz y el jurado en el Brasil imperial. México: Fondo de Cultura Económica, 1986.

DOLHNIKOFF, Miriam. O pacto Imperial: origens do federalismo no Brasil. São Paulo: Globo, 2005.

GOUVÊA, Maria de Fátima Silva. O Império das Províncias. Rio de Janeiro, 1822-1889. Rio de Janeiro: Civilização Brasileira, 2008.

GRAHAM, Richard. Clientelismo e política do Brasil no século XIX. Rio de Janeiro: Editora UFRJ, 1997.

IGLESIAS, Francisco. Vida política, 1848/1868. In: HOLANDA, Sérgio Buarque de. História Geral da Civilização Brasileira. O Brasil Monárquico: reações e transações, t. II, v. 3, Rio de Janeiro: Bertrand Brasil. 1987.

MACHADO, Maria Helena. O plano e o pânico: os movimentos sociais na década da Abolição. Rio de Janeiro: Ed. UFRJ, 1994.

MARQUESE, Rafael de Bivar. Capitalismo, escravidão e a economia cafeeira do Brasil no longo século XIX. Saeculum - Revista de História, n.29, jul./dez. 2013. p. 289-321.

MATTOS, Hebe Maria. Das cores do silêncio: os significados da liberdade no Sudeste escravista - Brasil, século XIX. Rio de Janeiro: Nova Fronteira, 1998.

MATTOS, Ilmar Rohloff de. O tempo saquarema. São Paulo: Hucitec, 2004.

MELLO, Geraldo C. de. Os Almeidas e os Nogueiras de Bananal. São Paulo: Instituto Genealógico Brasileiro. s/d.

MENDONÇA, Joseli Maria Nunes. Entre a mão e os anéis: a lei dos sexagenários e os caminhos da abolição no Brasil. Campinas, SP: Ed. da Unicamp, 2008. 
NEEDELL, Jeffrey D. Politics, Parliament, and the Penalty of the lash: The Significance of the End of Flogging in 1886. Almanack: revista eletrônica. Guarulhos: UNIFESP, n. 4, p. 91-100, nov. de 2012.

PARRON, Tâmis. A política da escravidão no Império do Brasil, 1826-1865. Rio de Janeiro: Civilização Brasileira, 2011.

QUEIROZ, Jonas Marçal de. Da senzala à República: tensões sociais e disputas partidárias em São Paulo (1869-1889). 1995. Dissertação (Mestrado em História) - Instituto de Filosofia e Ciências Humanas, Universidade Estadual de Campinas, Campinas, 1995.

RAMOS, Agostinho. Pequena História do Bananal. São Paulo: Gráfica Sangirard, 1975.

REVEL, Jacques. Microanálise e construção do social. In: (org). Jogos de escala: a experiência da microanálise. Rio de Janeiro: Editora FGV, 1996.

RODRIGUES, Jaime. 0 infame comércio: propostas e experiências no final do tráfico de africanos para o Brasil (1800-1850). Campinas: Ed. da UNICAMP/CECULT, 2000.

SALLES, Ricardo. E o Vale era o escravo: Vassouras, século XIX. Senhores e escravos no coração do Império. Rio de Janeiro: Civilização Brasileira: 2008.

. Abolição no Brasil: resistência escrava, intelectuais e política (18701888). Revista de Índias, Madrid, vol. LXXI, 2011, 251: 259-284. . 0 Império do Brasil no contexto do século XIX. Escravidão nacional, classe senhorial e intelectuais na formação do Estado. Almanack: Guarulhos/SP: UNIFESP, n. 4, nov. de 2012. pp. 5-45.

SANTOS, Marco Aurélio dos. Geografia da escravidão na crise do Império: Bananal, 1850-1888. 2014. 281 f. Tese (Doutorado) - Faculdade de Filosofia, Letras e Ciências Humanas, Universidade de São Paulo, São Paulo, 2014.

SLENES, Robert W. Grandeza ou decadência? 0 mercado de escravos e a economia cafeeira da Província do Rio de Janeiro, 1850-1888. In: COSTA, Iraci Del Nero da. (org.) Brasil: história econômica e demográfica. São Paulo: Instituto de Pesquisas Econômicas, 1986.

The Brazilian internal slave trade, 1850-1888: regional economies, slave experience, and the politics of a peculiar market. In: JOHNSON, Walter. The chattel principle: the internal slave trade in the Americas. New Haven \& London: Yale University Press. 2004.

SOARES DE SOUZA, Francisco Belisário. 0 sistema eleitoral no Império. Brasilia: Senado Federal, 1979.

STEIN, Stanley J. Grandeza e decadência do café no Vale do Paraiba - com referência especial ao município de Vassouras. São Paulo: Brasiliense, 1961.

TOPLIN, Robert Brent. The abolition of slavery in Brazil. New York: Atheneum, 1975.

VITORINO, Artur José Renda \& SOUSA, Eliana Cristina Batista de. "0 pássaro e a sombra": instrumentalização das revoltas escravas pelos partidos políticos na província de São Paulo nas últimas décadas da escravidão. Estudos Históricos, Rio de Janeiro, v. 21, n. 42, p. 303322, jul.-dez. de 2008. 